\title{
TAXONOMIC STUDIES OF THE SUBGENUS HELCOCYRTOMYIA. I. SERIES OSWALDOI (DIPTERA, PSYCHODIDAE, PHLEBOTOMINAE)
}

\author{
EDELBERTO SANTOS DIAS; ALDA LIMA FALCÃO; JOÃO EVANGELISTA DA \\ SILVA* \& AMILCAR VIANNA MARTINS ${ }^{*}$
}

\author{
Centro de Pesquisas Rene Rachou - FlOCRUZ, Caixa Postal 1743, 30190 Belo Horizonte, \\ MG, Brasil *Departamento de Parasitologia, ICB, UFMG, Belo Horizonte, MG, Brasil
}

Attempting to review the species of sandflies in the series oswaldoi of the subgenus Helcocyrtomyia, we examined 7650 specimens collected in different Brazilian regions during $\$ 5$ years and deposited in the collection of the Centro de Pesquisas René Rachou, FIOCRUZ, Belo Horizonte, MG. As main results of this study, two new species of Helcocyrtomyia were described (Lutzomyia pusilla and Lutzomyia capixaba), in addition to the females of Lutzomyia ferreirana and Lutzomyia peresi; which had been described only by the males. The geographic distribution of the material examined is also presented.

Key words: taxonomy - Phlebotominae - series oswaldoi - Helcocyrtomyia - geographic distribution

From the epidemiological point of view, the genus Lutzomyia França, 1924 is of particular importance amongst the phlebotomine sandflies. It comprises species involved in the transmission of visceral and cutaneous leishmaniasis, bartonelosis and also of some parasites of lizards, toads, bats, sloaths and rodents from the genera Plasmodi. um, Trypanosoma and Endotrypanum (Anderson \& Ayala, 1968; Ayala \& Lee, 1970; Ayala, 1971 a,b; Forattini, 1973; Pessoa \& Martins, 1986).

Although not commonly involved in the transmission of diseases, and only suspected as possible vectors of bartonelose to humans (Shannon, 1929; Noguchi et al., 1929; Hertig, 1942) and of malaria and trypanosomiasis to coldblood animals (Anderson \& Ayala, 1968; Ayala \& Lee, 1970; Ayala, 1971 a,b), Helcocyrtomyia stands out as the most primitive subgenus of Lutzomyia. The finding of a fossil species, Lutzomyia (Helcocyr. tomyia) paterna Quate, in Mexican amber (oligocen/miocen), very similar to those present today within the subgenus, their widespread geographic distribution and their feeding on reptiles have all been taken as evidence for their being primitive (Shannom, 1913; Packchanian, 1946;

Work supported in part by FIOCRUZ and CNPq (Brazil). Part of PhD thesis (E. S. Dias).

Received 22 February 1991.

Accepted 10 June 1991.
Chaniotis \& Anderson, 1964; Ayala \& Lee, 1970; Ayala, 1971 a,b). This accounts for the great similarity of their morphological characteristics, which renders their identification, at the species level, difficult.

The subgenus Helcocyrtomyia, as defined by Barretto in 1962 (Martins et al., 1978), comprises' species with a long fifth palpal segment, greater in length than the third segment and sometimes longer than the combined lengths of segments 3 and 4 . The ascoids are usually short or very short.

The males show five spines in the distystile, of wich two are terminal and the others are unpaired. The basistyle has an inner basal tuft, which may be compact or difuse or, at times, composed of so few hairs that the tuft seems to be absent. The paramere is simple and unadorned, and the lateral lobe is unarmed. The cibarium of the female has four horizontal teeth, and may or may not have vertical teeth; the pigment patch is well-defined or pale; the cibarial arch is incomplete, and often laterally flared. The pharynx of several species is armed with spines. The body of the spermatheca is capsulate, with or without annulations and with a welldeveloped "head"; individual spermathecal ducts are long and narrow and the common duct is very short or absent.

Attempting to make taxonomic studies of $\mathrm{Hel}$ cocyrtomyia easier, Martins et al. (1978) proposed the division of the Helcoyrtomyia species 
into three series (oswaldoi, peruensis and vexator), based not only on morphological characters but alsc on some data concerning geographic distribution. Even though they lack taxonomic status, these series have been used throughout this study.

The present papsi reviews the species pertaining to the series oswaldoi. In the series oswaldoi, as proposed by Martins et al. (1978), the cibarium of the female lacks vertical teeth, the body of the spermatheca is pear-shaped or weakly annulated with a globose terminal segment, or sausage-shaped with smooth walls.

\section{MATERIALS AND METHODS}

This work was based on material collected in different Brazilian states and also in some other South American countries (Peru, Venezuela and French Guyana) between 1955 to 1989 and deposited in the American Phlebotominae collection at the Centro de Pesquisas René Rachou (CPqRR), Fundação Oswaldo Cruz (FIOCRUZ), Belo Horizonte, Brazil.

Appropriate methods for phlebotominae capture were employed (Barretto \& Coutinho, 1940; Sherlock \& Pessoa, 1964). Three different attractive traps, based on luminous bait, were used: Shannon (Shannon, 1939), Chaniotis (Chaniotis \& Anderson, 1968) and Falcão (Falcão, 1981) traps. The Damasceno trap (Damasceno, 1955) was used for capture in natural habits, such as tree trunks, wild animal burrows and stone crevices. Additionally, manual captures were made with the aid of a Castro aspirator, after disturbing the sandflies hiding-places with faggots or cigarette smoke.

The captured specimens were packed into hemolysis glass tubes containing commercial alcohol. Cotton compresses were finally introduced into the tubes for specimen protection during transportation. All the material was mounted on glass slides, using Canada balsam for the males and Berlese liquid for the females, and later examined in the laboratory.

The sandflies were identified using specific descriptions, taxonomic keys, comparison with species of the standard collection and mictometry data. Additional information was provided by drawing the available specimens in a light chamber.

The classification adopted in this work was that proposed by Martins et al. (1978).

\section{RESULTS}

In our work, 8887 specimens of Helcocyrtomyia sandflies were examined. Among these, 7650 belonged to the series oswaldoi; the remaining were from the series vexator and peruensis. Only the first series (oswaldoi) will be dealt with in the present paper. The Table summarizes the species distribution of the examined material.

\section{Lutzomyia (Helcocyrtomyia) appendiculata} Martins, Falcão \& Silva (Fig. 1: a, b)

Lutzomyia appendiculata Martins, Falcão \& Silva, 1961. Rev. Bras. Biol., 21: $297-299$ (male).

Lutzomyia (Trichopygomyia) appen. diculata Forattini, 1971. Pap. Av. Zool., \&4: 102 (male). Forattini, 1973, Entomol. Med. 4th vol.: 302 (male).

Type: holotype male deposited in CPqRR, FIOCRUZ, Belo Horizonte, MG, Brazil. Type locality: Uberaba Farm, Jequitinhonha town, Minas Gerais state, Brazil.

Geographic distribution: BRAZIL - Minas Gerais - Jequitinhonha (16 $26^{\circ} \mathrm{S}$; $\left.41^{\circ} 00^{\prime} \mathrm{W}\right)$.

This species belongs, undouptedly, to the subgenus Helcocyrtomyia, such as defined by Barretto (1962). The female of L. appendiculata has not yet been described, whereas the male has been observed out just once. L. appendiculata is easily identified by the presence of an appendix in the posterior part of the paramere, from which originated its name. This special character does not appear in any other species within the subgenus.

\section{Lutzomyia (Helcocyrtomyia) borgmeieri Martins, Falcão \& Silva (Fig. 1: c, d, e, f)}

Lutzomyia borgmeieri Martins, Falcão \& Silva, 1972. Studia Entomol., 15: 497-501 (male and female).

Types: holotype male (no. 32772) and allotype female (no. 32793), both deposited in CPqRR, FIOCRUZ, Belo Horizonte, MG, Brazil. Type locality: Belo Horizonte town, Minas Gerais state, Brazil.

Geographic distribution: BRAZIL - Es. pírito Santo - Colatina (19 $31^{\prime} \mathrm{S}$; $40^{\circ} 37^{\prime} \mathrm{W}$; 

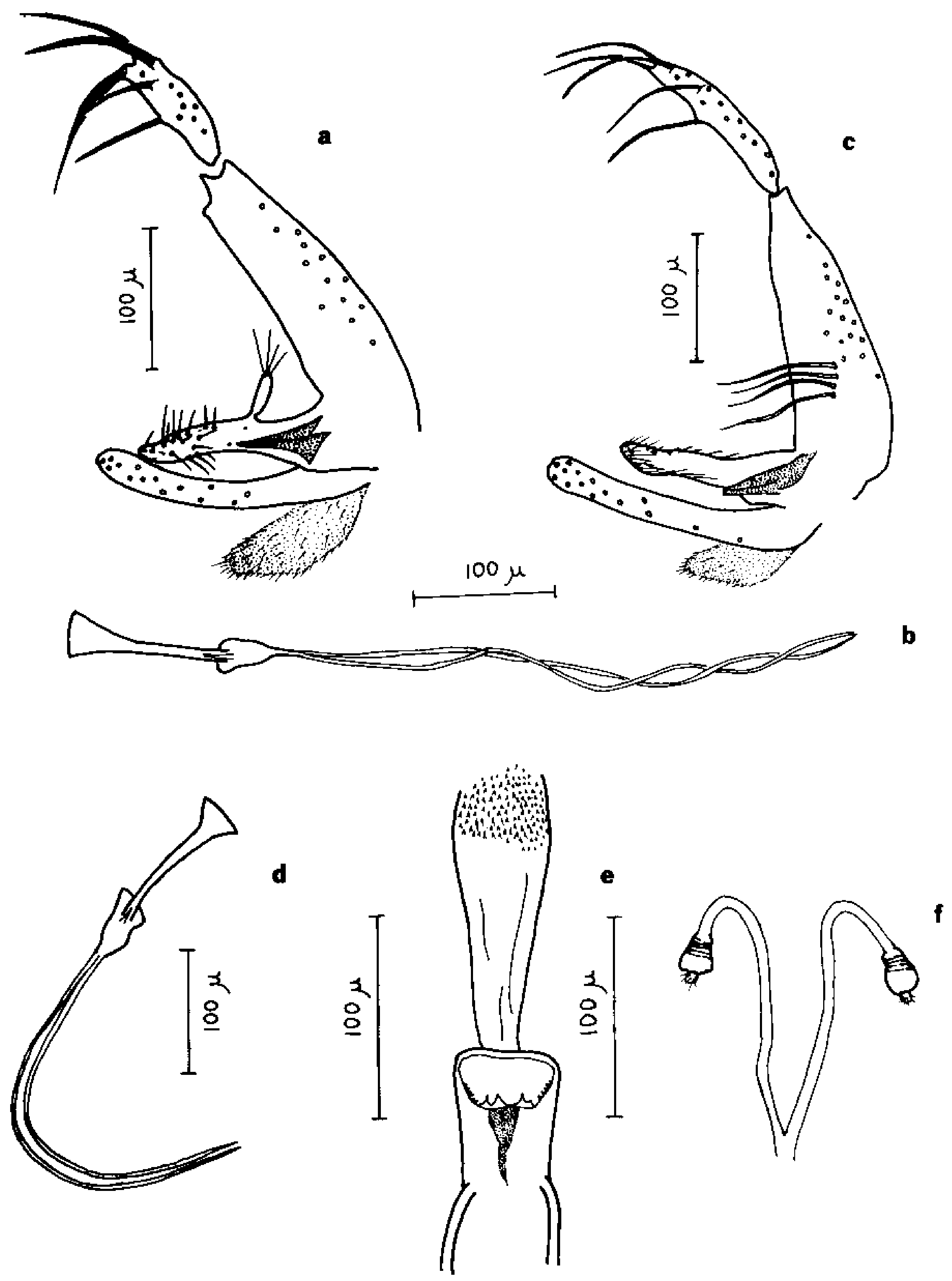

Fig. 1: Lutzomyia appendiculata - a: terminalia; b: genital pump and filaments. Lutzomyia borgmeieri - c: terminalia; d: genital pump and filaments; e: pharynx and cibarium; f: spermathecae.

Viana (20 $\left.23^{\prime} \mathrm{S} ; 40^{\circ} 29^{\prime} \mathrm{W}\right)$. Minas Gerais-Belo Horizonte $\left(19^{\circ} 55^{\prime} \mathrm{S} ; 43^{\circ} 56^{\prime} \mathrm{W}\right)$; Dom Joaquim $\left(18^{\circ} 57^{\prime} \mathrm{S} ; 43^{\circ} 16^{\prime} \mathrm{W}\right)$; Iapu $\left(19^{\circ} 26^{\prime} \mathrm{S} ; 42^{\circ} 13^{\prime} \mathrm{W}\right)$; Galiléia $\left(19^{\circ} 00^{\prime} \mathrm{S} ; 41^{\circ} 33^{\prime} \mathrm{W}\right)$; Jequitinhonha $\left(16^{\circ} 26^{\prime} \mathrm{S} ; 41^{\circ} 00^{\prime} \mathrm{W}\right)$; Lagoa Santa $\left(19^{\circ} 38^{\prime} \mathrm{S}\right.$; $\left.43^{\circ} 53^{\prime} \mathrm{W}\right)$; Patos de Minas ( $18^{\circ} 35^{\prime} \mathrm{S}$; $46^{\circ} 32^{\prime} \mathrm{W}$ );

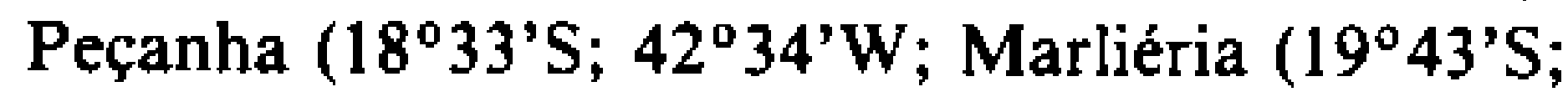
$42^{\circ} 45^{\prime} \mathrm{W}$ ); Monsenhor Paulo (21 ${ }^{\circ} 06^{\prime} \mathrm{S}$; $45^{\circ} 33^{\prime} \mathrm{W}$ ); Morro do Pilar $\left(19^{\circ} 12^{\prime} \mathrm{S}\right.$; $\left.43^{\circ} 23^{\prime} \mathrm{W}\right)$ Rio Preto

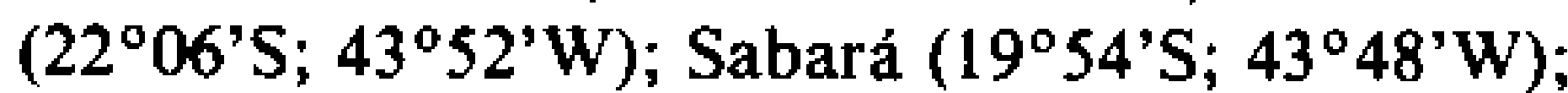
São João Evangelista ( $\left(18^{\circ} 32^{\prime} \mathrm{S}\right.$; $\left.42^{\circ} 45^{\prime} \mathrm{W}\right)$; Simoné-

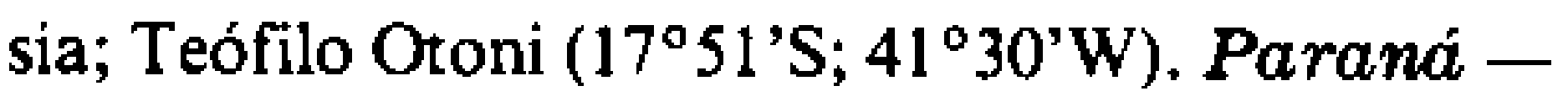

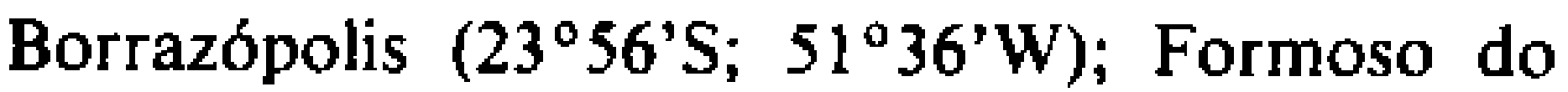

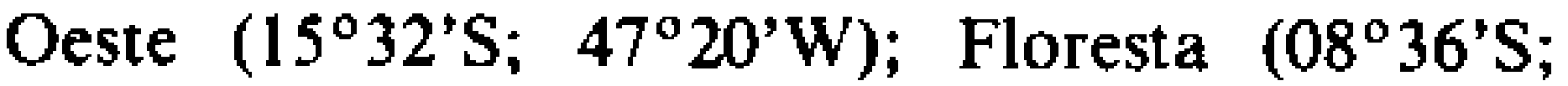
$\left.38^{\circ} 36^{\prime} \mathrm{W}\right)$; Reserva $\left(08^{\circ} 36^{\prime} \mathrm{S}\right.$; $\left.38^{\circ} 34^{\prime} \mathrm{W}\right)$. Rio de Janeiro - Rio de Janeiro ( $22^{\circ} 54^{\prime} \mathrm{S}$; $\left.43^{\circ} 14^{\prime} \mathrm{W}\right)$. Rio Grande do Sul - Tenente Portela $\left(27^{\circ} 20^{\prime}\right.$ 'S;

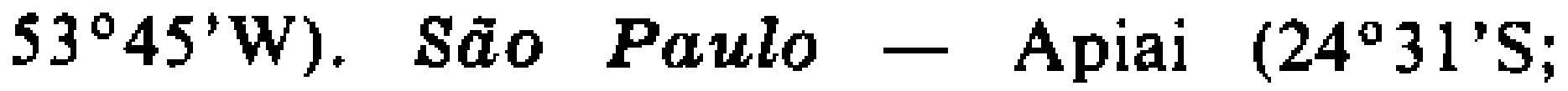
$\left.48^{\circ} 50^{\prime} \mathrm{W}\right)$.

The male can be distinguished from males of other species in the subgenus by the presence of a 
tuft with four to five bristles arranged in a row on the anterior third of the basistyle and by the arrangement of the spines of the dististyle: two apicals, one subapical and two thinner ones inserted at different levels on the median region of the dististyle. The female of $L$. borgmeieri differs from the females of other species by having a pharynx armed with stout spines, a cibarium showing four horizontal well-developed teeth, a pear-shaped spermathecae with three to four segments, the last one being more developed; and thick individual ducts whose walls are chitinized at their nearest part.

Among all the species in the subgenus $\mathrm{Hel}$. cocyrtomyia, L. oswaldoi, L. capixaba and $L$. ferreirana are those that most resemble $L$. borgmeieri, due to the similarity of their spermathecae. However, $L$. oswaldoi possesses an unarmed pharynx, differing from L. borgmeieri, $L$. capixaba and L. ferreirana the pharynx of which are armed with stout spines. The distinction between $L$. borgmeieri and $L$. ferreirana is by means of cibarium: L. ferreirana shows a chitinous structure among its horizontal teeth besides two vertical outstanding teeth whereas this structure is lacking in $L$. borgmeieri. The width of the pharynx distinguishes $L$. capixaba from $L$. borgmeieri, as it is much wider in the first species.

\section{Lutzomyia (Helcocyrtomyia) capixaba}

Dias, Falcão, Silva \& Martins (Fig. 2: a, b, c, d)

Lutzomyia capixaba Dias, Falcão, Silva \& Martins, 1987. Mem. Inst. Oswaldo Cruz, 82: 193-196 (male and female).

Types: holotype male (no. 40284) and allotype female (no. 40451), both deposited in CPqRR, FIOCRUZ, Belo Horizonte, Brazil. Type locali $t y$ : Conquista, Baixo Guandu town, Espírito Santo state, Brazil.

Geographic distribution: BRAZIL - Bahia

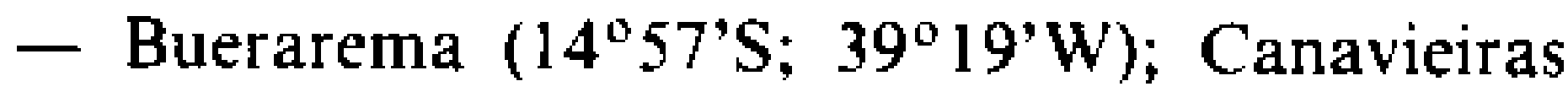

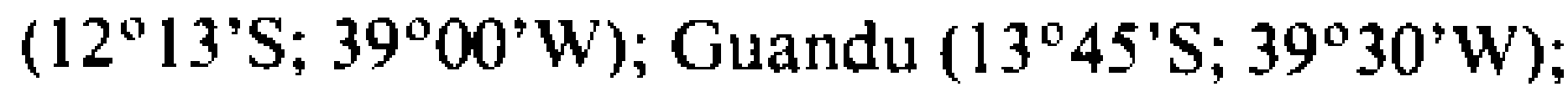
Ilhéus $\left(13^{\circ} 01^{\prime} \mathrm{S}\right.$; $\left.40^{\circ} 01^{\prime} \mathrm{W}\right)$; Itabuna $\left(14^{\circ} 48^{\prime} \mathrm{S}\right.$; $\left.39^{\circ} 16^{\prime} \mathrm{W}\right)$; ltajuipe $\left(14^{\circ} 41^{\prime} \mathrm{S}\right.$; 39 $\left.22^{\prime} \mathrm{W}\right)$; Itapebi

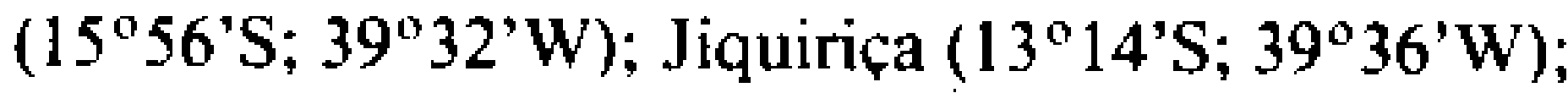

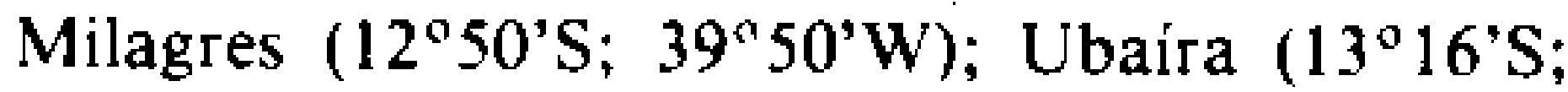
$\left.39^{\circ} 39^{\prime} \mathrm{W}\right)$; Ubatã $\left(14^{\circ} 12^{\prime} \mathrm{S}\right.$; 39'31'W); Uruçuca

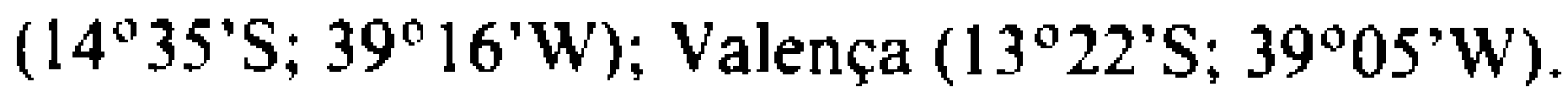
Espirito Santo - Baixo Guandu (19\%31'S; $\left.41^{\circ} 01^{\prime} \mathrm{W}\right)$; Itaguaçu (18 $\left.48^{\circ} \mathrm{S} ; 40^{\circ} 51^{\prime} \mathrm{W}\right)$. Minas Gerais - Bocaiúva $\left(17^{\circ} 07^{\prime} \mathrm{S} ; 43^{\circ} 49^{\prime} \mathrm{W}\right)$; Itan- homi $\left(19^{\circ} 10^{\prime} \mathrm{S} ; 4^{\circ} 52^{\prime} \mathrm{W}\right)$; Jacinto $\left(16^{\circ} 10^{\prime} \mathrm{S}\right.$; $\left.40^{\circ} 17^{\prime} \mathrm{W}\right)$; Mato Verde (16 ${ }^{\circ} 05^{\prime} \mathrm{S}$; $\left.40^{\circ} 56^{\prime} \mathrm{W}\right)$; Monte

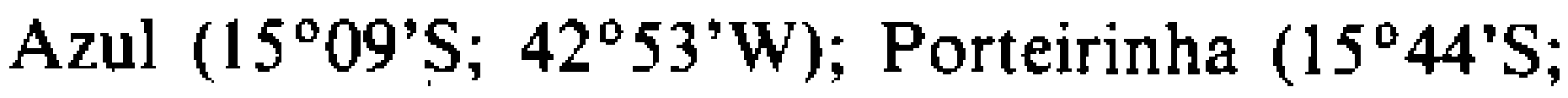
$\left.43^{\circ} 02^{\prime} \mathrm{W}\right)$; Janaúba (15\%48'S; $\left.43^{\circ} 19^{\prime} \mathrm{W}\right)$; Januária $\left(15^{\circ} 29^{\prime} \mathrm{S}\right.$; $\left.44^{\circ} 22^{\prime} \mathrm{W}\right)$; São João da Ponte

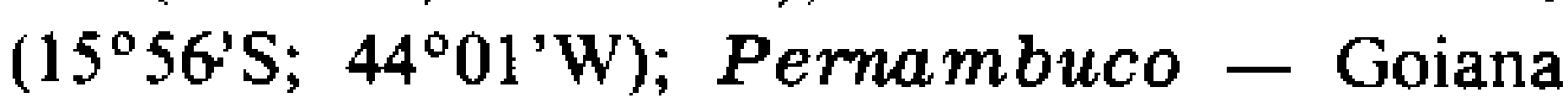

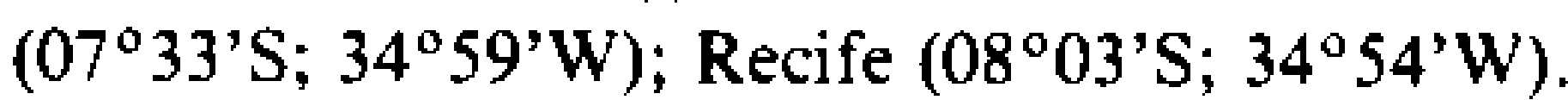

The male and female of $L$. capixaba were first described by Dias et al. (1987). The male most resembles $L$. oswaldoi. The distinguishing characteristics between these species are the greater size and the presence of a basal tuft in the basistyle of L. oswaldoi.

The spermathecae of both females is very similar, but $L$. capixaba possesses a wider pharynx armed with strong conspicous spines and a simple cibarium with a complete chitinous structure among the cibarial teeth, plus a striking pigment patch. The chitinous arch is indiscernible in the middle. In $L$. oswaldoithe pharynx is unarmed and the chitinous arch is incomplete.

\section{Lutzomyia (Helcocyrtomyia) ferreirana} (Barretto, Martins \& Pellegrino) (Fig. 2: e, f, g, h)

Sergentom yia ferreirana Barretto, Martins \& Pellegrino, 1956. Fol. Clin. Biol., 26: 52-53, 56 (macho). Barretto, Martins \& Pellegrino, 1958. Rev. Bras. Malariol. D. Trop., 10: 187-188, 193 (male).

Lutzomyia (Trichopygom yia) ferreirana Forattini, 1971. Pap. Av. Zool., 24: 102. Forattini, 1973. Entomol. Med. 4th vol. : 306 (male).

Lutzomyia ( Helcocyrtomyia) ferreirana Dias, Falcão, Silva \& Martins, 1989. Mem. Inst. Oswaldo Cruz, 84: 245-248 (male and female).

Types: holotype male deposited in the collection of the Departamento de Parasitologia, Faculdade de Medicina de Ribeirão Preto, São Paulo, Brazil. Female deposited in CPqRR, FlOCRUZ, Belo Horizonte, MG, Brazil. Type locality: Itambacuri town, Minas Gerais state, Brazil.

Geographic distribution: BRAZIL - Es. pirito Santo - Santa Tereza (19 $\left.{ }^{\circ} 55^{\prime} \mathrm{S} ; 40^{\circ} 36^{\prime} \mathrm{W}\right)$; São Roque da Terra Roxa $\left(19^{\circ} 01^{\prime} \mathrm{S} ; 40^{\circ} 32^{\prime} \mathrm{W}\right)$. $M i$ nas Gerais - Belo Horizonte (19\%5 'S; $\left.43^{\circ} 56^{\prime} \mathrm{W}\right)$; Caratinga (19'37'S; $\left.42^{\circ} 08^{\prime} \mathrm{W}\right)$; Dom

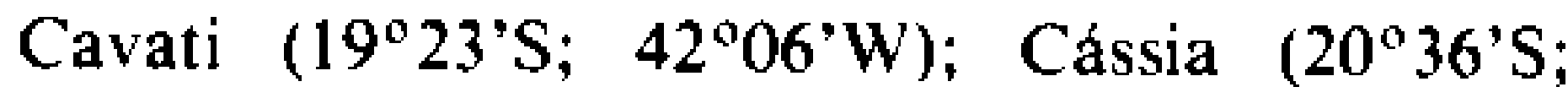
$\left.46^{\circ} 56^{\prime} \mathrm{W}\right)$; Conselheiro Pena (17 ${ }^{\circ} 10^{\prime} \mathrm{S} ; 41^{\circ} 30^{\prime} \mathrm{W}$ );

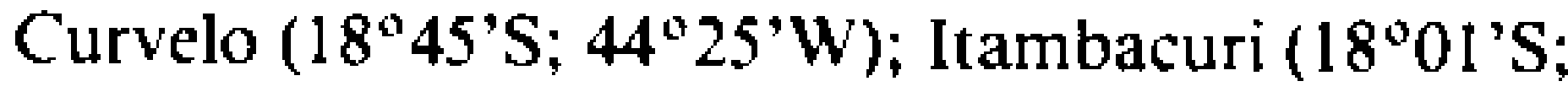
$\left.41^{\circ} 42^{\prime} \mathrm{W}\right)$; Itanhomi (19 $9^{\circ} 10^{\prime} \mathrm{S}$; $\left.41^{\circ} 52^{\prime} \mathrm{W}\right)$; Passa- 

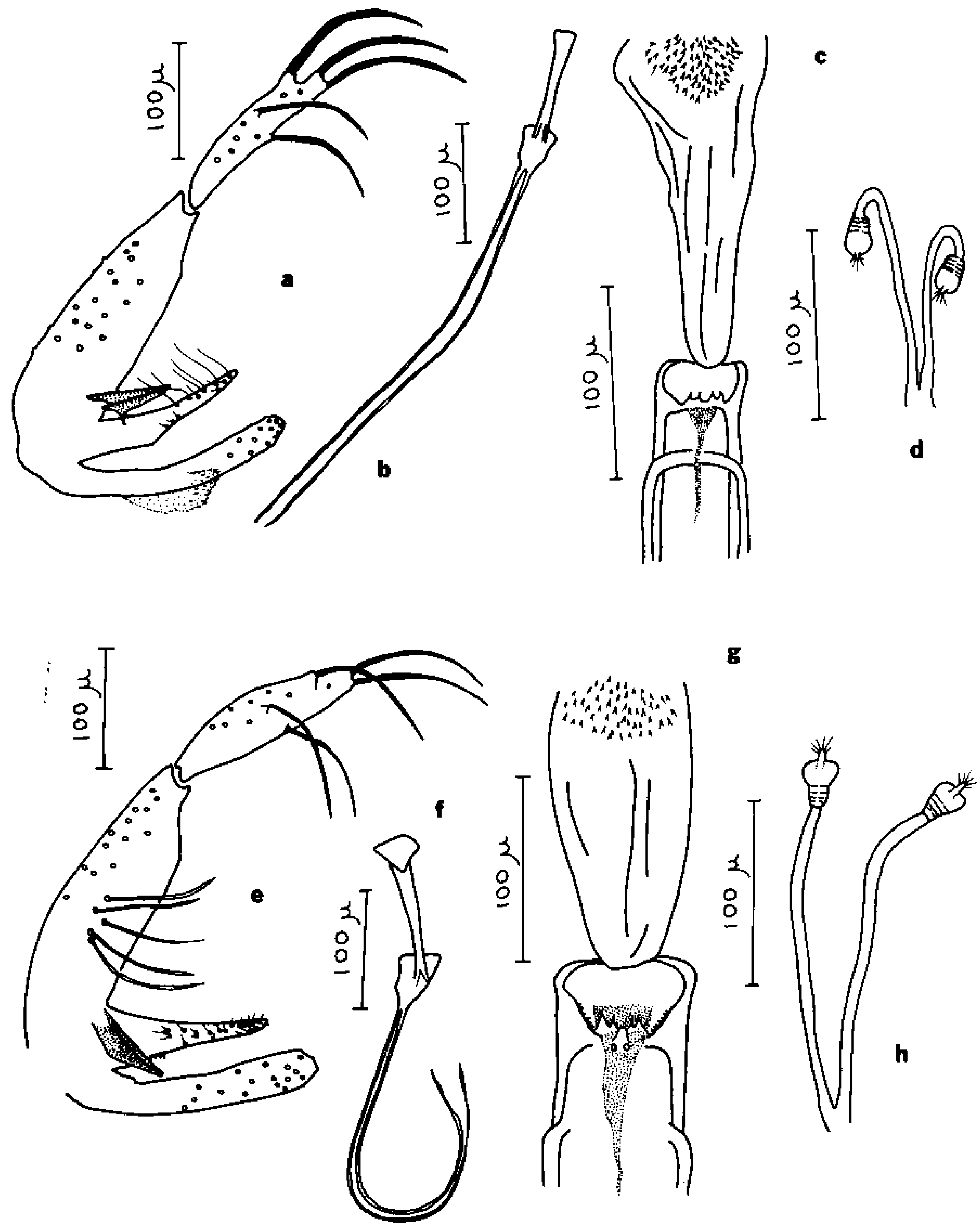

Fig. 2: Lutzomyia capixaba - a: terminalia; b: genital pump and filaments; c: pharynx and cibarium; d: spermathecae. Lutzomyia ferreirana - e: terminalia; f: genital pump and filaments; g: pharynx and cibarium; h: spermathecae.

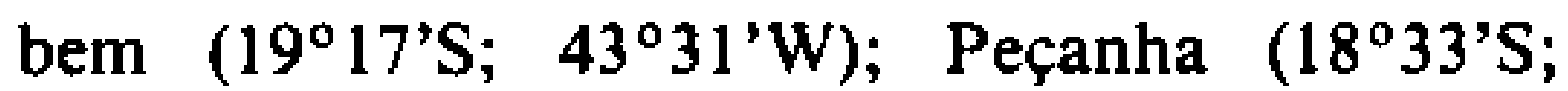
$\left.42^{\circ} 34^{\prime} \mathrm{W}\right)$; Prudente de Morais $\left(19^{\circ} 29^{\prime} \mathrm{S}\right.$; $\left.49^{\circ} 52^{\prime} \mathrm{W}\right)$; São João Evangelista (18 32'S; $\left.42^{\circ} 45^{\prime} \mathrm{W}\right)$; São João do Oriente $\left(19^{\circ} 21^{\prime} \mathrm{S}\right.$; $42^{\circ} 09^{\prime}(\mathrm{W})$.

The male of $L$. ferreirana is very similar to that of $L$. oswaldoi, due to the number of setae of the basistyle tuft as well as the arrangement of the spines in the dististyle. The main differences are the shapes of basistyle, dististyle, paramere and genital pump. Other males similar to $L$. fer reirana are those of $L$. capixaba and $L$. Iongipennis. L. capixaba lacks the basal tuft of setae that is observed in the basistyle of $L$. ferreirana. The distinction between $L$. Iongipennis and $L$. ferreirana is by the greater number of setae in the basistyle of $L$. Iongipennis (ca. 14), and by the arrangement of spines in the dististyle that differs between the species. The male of $L$. ferreirana was redescribed by Dias et al. (1989). 
The females of $L$. oswaldoi and $L$. borg. meieri are those most like the female of $L$. ferreirana, but the latter shows two cibarial horizontal teeth, besides two outstanding vertical teeth.

The female of $L$. ferreirana was correlated to the male by Dias et al. (1989).

\section{Lutzomyia (Helcocyrtomyia) goiana}

Martins, Falcão \& Silva (Fig. 3: a, b, c, d)

Lutzomyia goiana Martins, Falcão \& Silva, 1962. Rev. Bras. Malariol. D. Trop., 14: 383-385, 396, 397 (male and female). Lutzomyia(Trichopygomyia)goiana Forattini, 1971. Pap. Av. Zool., 24: 102.

Lutzomyia (Trichopygomyia) trinidadensis (pro parte) Forattini, 1973. Entomol. Med., 4th vol.: 321 (male and female).

Types: holotype female (numbered 14230) and allotype male (no. 14246) deposited in CPqRR, FIOCRUZ, Belo Horizonte, Minas Gerais, Brazil. Type locality: Poções farm, Sitio d'Abadia town, Goiás state, Brazil.

Geographic distribution: BRAZIL - Bahia - Barreiras $\left(12^{\circ} 08^{\prime} \mathrm{S} ; 45^{\circ} 00^{\prime} \mathrm{W}\right)$; Milagres $\left(12^{\circ} 50^{\prime} \mathrm{S} ; 39^{\circ} 50^{\prime} \mathrm{W}\right)$. Ceará - Icó $\left(06^{\circ} 24^{\prime} \mathrm{S}\right.$; $\left.38^{\circ} 51^{\prime} \mathrm{W}\right)$ : Pacatuba $\left(03^{\circ} 58^{\prime} \mathrm{S}\right.$; $\left.38^{\circ} 37^{\prime} \mathrm{W}\right)$; Pacoti $\left(04^{\circ} 13^{\prime} \mathrm{S}\right.$; 38 $\left.36^{\circ} \mathrm{W}\right)$; Maranguape $\left(03^{\circ} 53^{\prime} \mathrm{S}\right.$; $\left.38^{\circ} 40^{\prime} \mathrm{W}\right)$. Goiás - Amaro Leite $\left(13^{\circ} 58^{\prime} \mathrm{S}\right.$; $\left.49^{\circ} 09^{\prime} \mathrm{W}\right)$; Arraias $\left(12^{\circ} 56^{\prime} \mathrm{S}\right.$; $\left.46^{\circ} 57^{\prime} \mathrm{W}\right)$; Sítio D'Abadia $\left(14^{\circ} 48^{\prime} \mathrm{S}\right.$; $\left.46^{\circ} 16^{\prime} \mathrm{W}\right)$. Maranhão Coroatá $\left(04^{\circ} 08^{\circ} \mathrm{S} ; 44^{\circ} 08^{\prime} \mathrm{W}\right)$; Cururupu $\left(01^{\circ} 50^{\circ} \mathrm{S}\right.$; $\left.44^{\circ} 52^{\prime} \mathrm{W}\right)$; Paço do Lumiar ( $02^{\circ} 35^{\prime} \mathrm{S}$; $44^{\circ} 05^{\prime} \mathrm{W}$ ); São Luiz (02 $34^{\circ}$ 'S; $\left.44^{\circ} 16^{\prime} \mathrm{W}\right)$; Turiaçu $\left(01^{\circ} 41^{\prime}\right.$ 's; $45^{\circ} 21^{\prime} \mathrm{W}$ ); Viana ( $03^{\circ} 13^{\prime} \mathrm{S}$; $\left.45^{\circ} 00^{\prime} \mathrm{W}\right)$. Minas $\mathrm{Ge}$. rais - Januária ( $15^{\circ} 29^{\prime} \mathrm{S}$; $\left.44^{\circ} 22^{\prime} \mathrm{W}\right)$; Grão Mogol

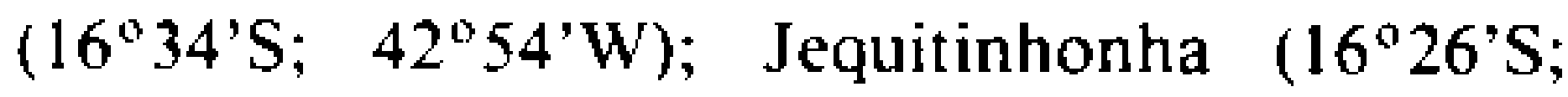

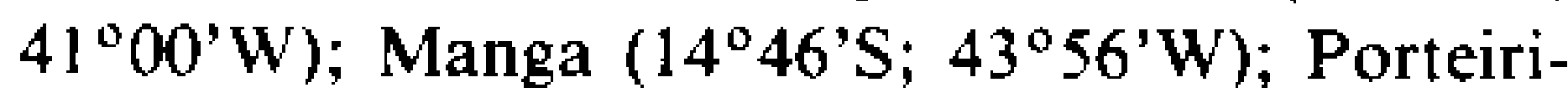
nha $\left(15^{\circ} 44^{\prime} \mathrm{S} ; 4^{\circ} 02^{\prime} \mathrm{W}\right)$; São João da Ponte (15 $\left.56^{\circ} \mathrm{S} ; 44^{\circ} 01^{\prime} \mathrm{W}\right)$. Mato Grosso do Sul Aquidauana $\left(20^{\circ} 28^{\prime} \mathrm{S} ; 55^{\circ} 48^{\prime} \mathrm{W}\right)$. Pará - Ananindeua $\left(01^{\circ} 22^{\prime} \mathrm{S} ; 48^{\circ} 23^{\prime} \mathrm{W}\right)$; Belém $\left(01^{\circ} 27^{\prime} \mathrm{S}\right.$; $\left.48^{\circ} 29^{\circ} \mathrm{W}\right)$; Castanhal $\left(01^{\circ} 18^{\prime} \mathrm{S} ; 4^{\circ} 55^{\prime} \mathrm{W}\right)$; Irituia

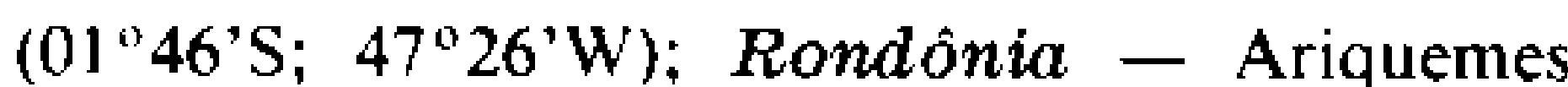
$\left(09^{\circ} 55^{\prime} \mathrm{S} ; 6^{\circ} 06^{\prime} \mathrm{W}\right)$; Guajará-Mirim $\left(10^{\circ} 48^{\prime} \mathrm{S}\right.$; $\left.65^{\circ} 22^{\prime} \mathrm{W}\right)$; Ji-Paraná $\left(08^{\circ} 45^{\prime} \mathrm{S}\right.$; $\left.62^{\circ} 20^{\prime} \mathrm{W}\right)$.

Among the Helcocyrtomyia species showing a tuft of bristles on the basistyle, L. trinidaden. sis is the most similar to $L$. goiana. They were considered as sibling species by Martins et al.
(1962), only distinguishable by the pharynx of the female: in $L$. trinidadensis there are stout and conspicous spines on the central part of the distal segment of the pharynx, whereas in L. goiana there are small hardly-visible spines only in the distal part of the pharynx, disposed in parallel rows. Forattini (1973) considered them as synonymy, judging this slight difference insufficient to characterize them as different species.

In this work, we found some females showing morphological characteres similar to those of $L$. goiana and $L$. trinidadensis, but without spines in the pharynx, in Maranhão State (Brazil). The males captured with these females were indistinguishable from $L$. goiana, without further study.

We examined a large number of specimens of $L$. goiana and $L$. trinidadensis from various Brazilian regions and some morphological differences were found between the species. $L$. goiana shows a simple enlarged-base paramere that narrows and bends slightly upwards. It is commonly observed that in a single specimen each paramere has a different shape. This is due to the fact that this structure is flattened dorso-ventrally and during the mounting on glass slides it can suffer some rotation. In this case, the paramere seems to be larger and with a little projection on the top. The paramere in $L$. trinidadensis is enlarged in the base, narrowing markedly to the top; morever, the clypeus in both sexes is much more developed in L. trinidadensis.

The male of $L$. goiana can be easily distinguished from other similar males, such as $L$. rorotaensis and $L$. longipennis. The number of bristles in the basistyle is different in $L$. goiana and $L$. rorotaensis (10-14 for the first and 15-20 for the second). Both are distinguishable from L. longipennis by the insertion level of the basal pair of spines in the dististyle: in $L$. goiana and $L$. rorotaensis they are inserted at two different levels. Moreover, the tuft in the dististyle of $L$. goiana is composed of shorter narrower and more flexible bristles than in $L$. longipennis and the length/width ratio of the wings is greater in $L$. longipennis.

The female of $L$. trinidadensis is the most similar to L. goiana, due to the characteristics of the spermathecae. According to Martins et al. (1962) they can be distinguished by the distal third of the pharynx, but we verified an additional differ- 
ence. L. goiana shows a chitinous structure projecting among the cibarial horizontal teeth, that is lacking in L. trinidadensis. This structure is also observed in $L$. oswaldoi, $L$, peresi, and $L$. ferreirana, but all of them show different-shaped spermathecae, as compared to $L$. goiana.

\section{Lutzomyia (Helcocyrtomyia) longipennis (Barretto) (Fig. 3: e, f, g, h)}

Flebotomus longipennis Barretto, 1946. Rev. Bras. Biol., 6: 427-429 (macho). Lutzomyia longipennis Martins, Falcão \& Silva, 1962. Rev. Bras. de Malariol. D. Trop., 14: 390-391, 393, 400, 401 (male and female).

Lutzomyia (Trichopygomyia) longipennis Forattini, 1973. Entomol. Med. 4th vol., 307, 309 (male and female).

Types: holotype male deposited in the entomological collection of the Departamento de Parasitologia, Faculdade de Medicina da Universidade de São Paulo, São Paulo, Brazil. Allotype female (no. 20869) deposited in the collection of CPqRR, FIOCRUZ, Belo Horizonte, Minas Gerais, Brazil. Type locality: Monjolinho farm, Corumbá de Goiás town, Goiás state, Brazil.

Geographic distribution: BRAZIL - Acre - Rio Branco (08 ${ }^{\circ} 14^{\prime} \mathrm{S}$; $\left.73^{\circ} 13^{\prime} \mathrm{W}\right)$. A mazonas Careiro $\left(03^{\circ} 12^{\prime} \mathrm{S}\right.$; $\left.59^{\circ} 45^{\prime} \mathrm{W}\right)$; Manaus $\left(03^{\circ} 08^{\prime} \mathrm{S}\right.$; $\left.59^{\circ} 01^{\prime} \mathrm{W}\right) ;$ Amapá - Macapá $\left(00^{\circ} 02^{\prime} \mathrm{S}\right.$; $\left.51^{\circ} 03^{\prime} \mathrm{W}\right) ;$ Goiás - Amaro Leite (13'58'S;

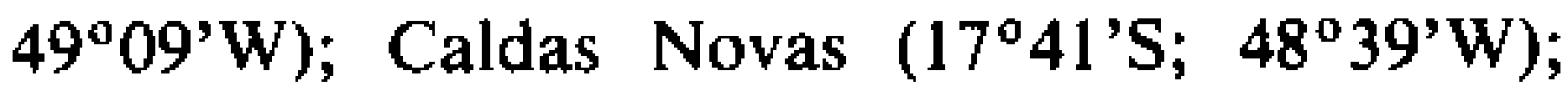
Ceres ( $\left.15^{\circ} 17^{\prime} \mathrm{S} ; 49^{\circ} 35^{\prime} \mathrm{W}\right)$; Corumbá de Goiás

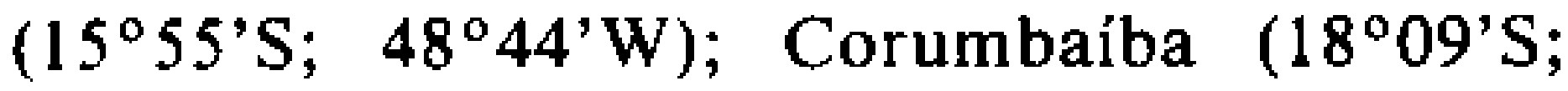
$\left.48^{\circ} 34^{\prime} \mathrm{W}\right)$; Porto Nacional $\left(10^{\circ} 42^{\prime} \mathrm{S}\right.$; $\left.48^{\circ} 25^{\prime} \mathrm{W}\right)$; Rianópolis (15 $30^{\prime} \mathrm{S}$; $\left.49^{\circ} 30^{\prime} \mathrm{W}\right)$; Sítio d'Abadia

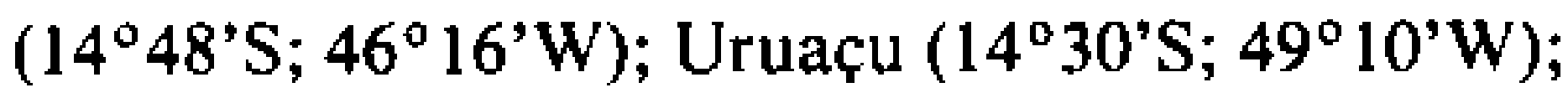
Maranhão - Coroatá $\left(04^{\circ} 08^{\prime} \mathrm{S} ; 4^{\circ} 08^{\prime} \mathrm{W}\right)$; Mato Grosso - Barra do Bugre (15 $05^{\prime} \mathrm{S}$; $\left.57^{\circ} 11^{\prime} \mathrm{W}\right)$; Barra do Garças (15 $53^{\prime} \mathrm{S}$; $52^{\circ} 15^{\prime} \mathrm{W}$ ); Diamantino (14 $25^{\prime} \mathrm{S}$; $\left.56^{\circ} 27^{\prime} \mathrm{W}\right)$; Mato Grosso do Sul -

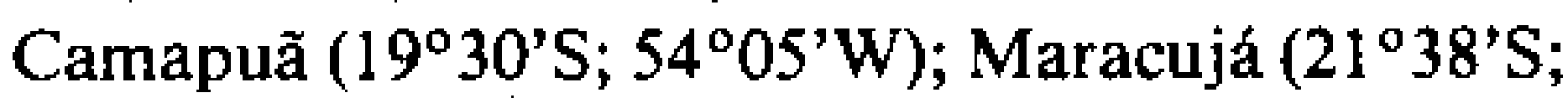
$\left.55^{\circ} 09^{\prime} \mathrm{W}\right)$; Minas Gerais - Arinos (15 $55^{\prime} \mathrm{S}$;

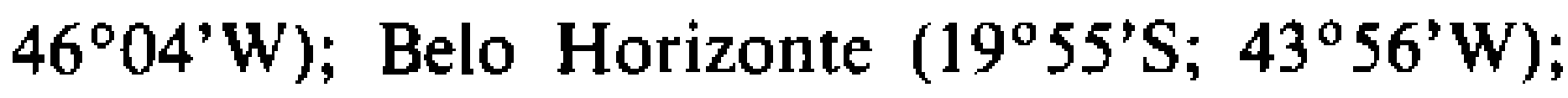

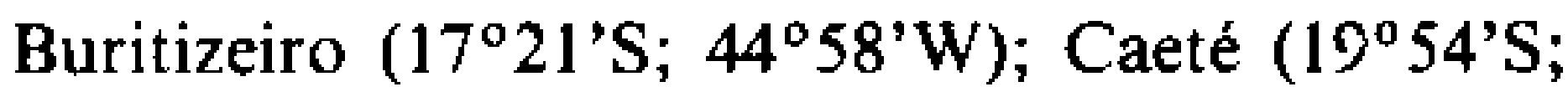

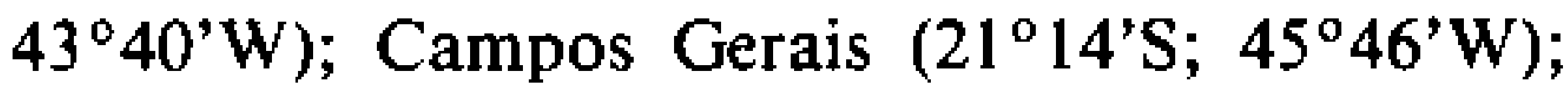
Carmo da Cachoeira $\left(21^{\circ} 28^{\prime} \mathrm{S} ; 4^{\circ} 13^{\prime} \mathrm{W}\right)$; Cássia

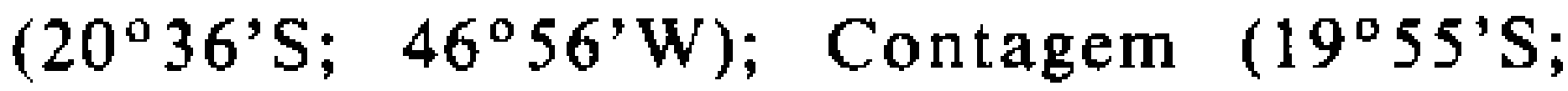
$44^{\circ} 06^{\prime} \mathrm{W}$ ); Corinto (18 $21^{\circ} \mathrm{S}$; $\left.44^{\circ} 27^{\prime} \mathrm{W}\right)$; Curvelo $\left(18^{\circ} 45^{\prime} \mathrm{S} ; 44^{\circ} 25^{\prime} \mathrm{W}\right)$; Esmeraldas $\left(19^{\circ} 45^{\prime} \mathrm{S}\right.$; $\left.44^{\circ} 19^{\prime} \mathrm{W}\right)$; Felixlândia (18 $47^{\prime} \mathrm{S}$; $\left.44^{\circ} 55^{\prime} \mathrm{W}\right)$; Janu-

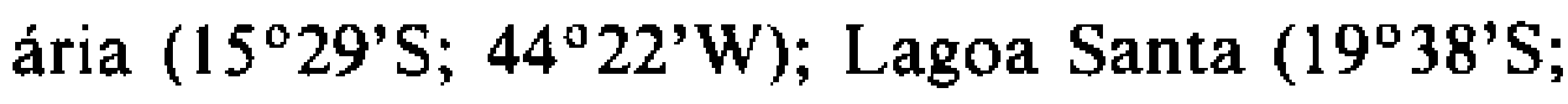

$\left.43^{\circ} 53^{\prime} \mathrm{W}\right)$; Matozinhos ( $19^{\circ} 35^{\prime} \mathrm{S}$; $\left.44^{\circ} 07^{\prime} \mathrm{W}\right)$; Oli-

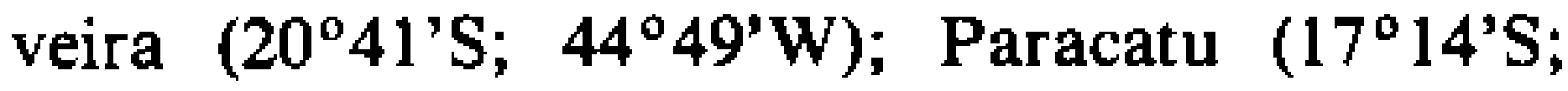
$\left.46^{\circ} 53^{\prime} \mathrm{W}\right)$; Sete Lagoas (19 $27^{\prime} \mathrm{S}$; $\left.44^{\circ} 14^{\prime} \mathrm{W}\right)$; Ta-

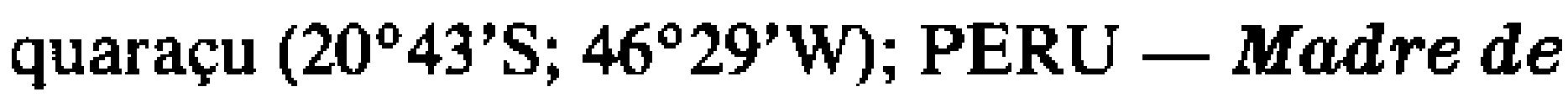
Dios - Ibéria $\left(05^{\circ} 48^{\prime} \mathrm{S} ; 7^{\circ} 00^{\prime} \mathrm{W}\right)$; Loreto Pucallpa (08 23 'S; $74^{\circ} 23^{\prime} \mathrm{W}$ ).

Lutzomyia longipennis belongs to the group of Helcocyrtomyia species possessing an inner basal tuft in the basistyle. L. longipennis is distinguished from the great majority of species in the subgenus by the number of setae in the tuft (ca. 14) and by the arrangement of spines in the distystile. However, these same features are present in $L$. trinidadensis, and the distinction between these species is by the shape of the paramere and by the level of implantation of basal spines in the dististyle. L. longipennis also exhibits the narrowest and longest wings among the species within the series oswaldoi and it is unique in that the genital filament is slender and curved (comma-shaped).

The female of $L$. longipennis shows a peculiar feature: a large segmented spermatheca, with a globose well-developed terminal segment. The cibarium has four regularly separated horizontal teeth. The pigmented patch is well-defined but short and the cibarial arch is incomplete. $L$. rorotaensis is very similar to $L$. longipennis but: (1) The length/width ratio of the wings is greater in $L$. longipennis; (2) The cibarial horizontal teeth are bent inwards in $L$. rorotaensis while in $L$. longipen$n$ is they are more developed, nearly equidistant and the distance between the inner pair is greater than the distance between inner and outer teeth.

\section{Lutzomyia (Helcocyrtomyia) machupicchu} Martins, Llanos \& Silva (Fig. 4: a, b)

Lutzomyia (Helcocyrtomyia) machupicchu Martins, Llanos \& Silva, 1975. Rev. Brasil. Biol., \$5: 652-653 (macho).

Type: holotype male (no. 46321) deposited in CPqRR, FIOCRUZ, Belo Horizonte, Minas Gerais, Brazil. Type locality: Machupicchu ruins, vale do Rio Urubamba, Provincia de la Convención, Cuzco Departament, Peru.

Geographic distribution PERU - Cuzco -

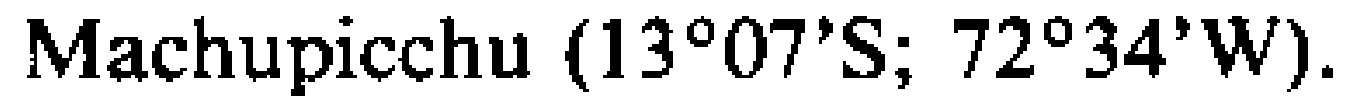

The Helcocyrtomyia species that most resemble L. machupicchu are L. capixaba, L. peresi 
and $L$. pusilla. Besides being the largest, $L$. machupicchu was found only in the Machupicchu region (Peru), while the other species are largely distributed over a large region of Brazil. According to Martins et al. (1975) L. machupicchu is characterized by having narrow and elongated wings (length/width $=5,53$ ) and by the relationship between wing veins: alpha smaller than beta and beta smaller than gama.

\section{Lutzomyia (Helcocyrtomyia) oswaldoi (Mangabeira) (Fig. 4: c, d, e, f)}

Flebotomus oswaldoi Mangabeira, 1942. Mem. Inst. Oswaldo Cruz, s7: 190-193 (male), 288-294 (female, pupa, larva, exuvia). Lut. zomyia (Trichopygomyia) oswaldoi Forattini, 1971. Pap. Av. Zool., 24: 102. Forattini, 1973. Entomol. Med., 4th vol., $312-314$ (male, female, pupa, larva).

Types: holotype male (no. 333) and allotype female (no. 485) deposited in Adolpho Lutz Laboratory, FIOCRUZ, Rio de Janeiro, Brazil. Type locality: Timbaúbas, Russas town, Ceará state.

Geographic distribution: BRAZIL - Bahia - Venceslau Guimarães. Ceará - Canindé

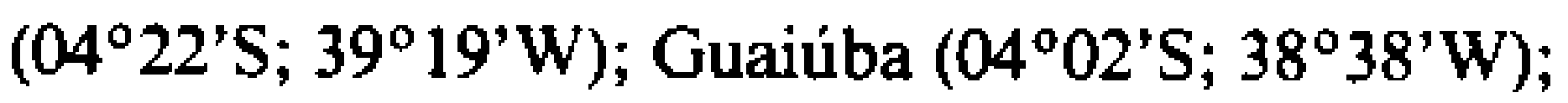
Maranguape $\left(03^{\circ} 53^{\prime} \mathrm{S}\right.$; $\left.38^{\circ} 40^{\prime} \mathrm{W}\right)$; Pacatuba $\left(03^{\circ} 58^{\prime} \mathrm{S} ; 38^{\circ} 37^{\prime} \mathrm{W}\right)$; Minas Gerais - Francisco Sá (16 $28^{\prime} \mathrm{S}$; $\left.43^{\circ} 30^{\prime} \mathrm{W}\right)$; Jequitinhonha (16 $26^{\circ} \mathrm{S}$; $41^{\circ} 00^{\prime} \mathrm{W}$ ); Piaui - Oeiras (07 ${ }^{\circ} 00^{\prime} \mathrm{S}$; $\left.42^{\circ} 05^{\prime} \mathrm{W}\right)$;

The arrangement of spines in the dististyle and the presence of a loose tuft in the inner part of the basistyle with c.a. six slender and flexuous setae are the main distinguishing features of $L$. oswaldoi. L. ferreirana and $L$. capixaba also exhibit a similar arrangement of spines but $L$. ferreirana shows a smaller and narrower dististyle as compared to $L$. oswaldoi, besides the paramere with a distinct shape. $L$. capixaba lacks basal tuft that is present in the basistyle of L. oswaldoi.

The spermathecae are very similar in three females of the series oswaldoi: L. oswaldoi, $L$. borgmeieri and $L$. ferreirana. But $L$. oswaldoi has a very characteristic cibarium with a chitinous structure projecting among the cibarial teeth and a striking pigment path. Moreover the pharynx in $L$. oswaldoi is unarmed while both, $L$. borgmeieri and $L$. ferreirana, show an armed pharynx.

\section{Lutzomyia(Helcocyrtomyia)paterna (Quate)}

Phlebotomus paternus Quate, 1963. J. Paleontol., s7: 113-114 (male).

Type: holotype male (no. 12746) deposited in Calif. Mus. Paleo. Califórnia, USA. Type locality: B-1402, Simojovel area, Chiapas $\left(17^{\circ} 00^{\prime} \mathrm{N}\right.$; $92^{\circ} 45^{\prime} \mathrm{W}$ ).

Lutzomyia paterna was found in the Mexican amber (oligocen/miocen), showing morphological characteristics identical to the present $\mathrm{Hel}$. cocyrtomyia species. According to Quate (1963) $L$. paterna resembles species from the genus Brumptomyia, group vexator (Fairchild, 1955).

\section{Lutzomyia (Helcocyrtomyia) peresi}

(Mangabeira) (Fig. 5: a, b, c, d, e)

Flebotomus peresi Mangabeira, 1942. Mem. Inst. Oswaldo Cruz, s7: 190-193 (male).

Phlebotomus (Brumptomyia)peresi Lucena \& Almeida, 1965. Rev. Bras. Malariol. $D$. Trop., 17: 261-262, 266, 268 (male and female).

Lutzomyia (Trichopygomyia) peresi Forattini, 1971. Pap. Av. Zool., 24: 102. Forattini, 1973, Entomol. Med. 4th vol.: 314 (male).

Lutzomyia (Helcocyrtomyia) peresi Dias, Martins, Falcão \& Silva, 1986. Mem. Inst. Os. waldo Cruz, 81: 215-219 (male and female).

Types: neotype male (no. 39846) and allotype female (no. 39827) both deposited in CPqRR, FIOCRUZ, Belo Horizonte, Minas Gerais, Brazil. Type locality: Lapão cave, Januária town, Minas Gerais, Brazil.

Geographic distribution: BRAZIL - Goiás - Amaro Leite $\left(13^{\circ} 58^{\prime} \mathrm{S}\right.$; $\left.49^{\circ} 09^{\prime} \mathrm{W}\right)$; Arraias

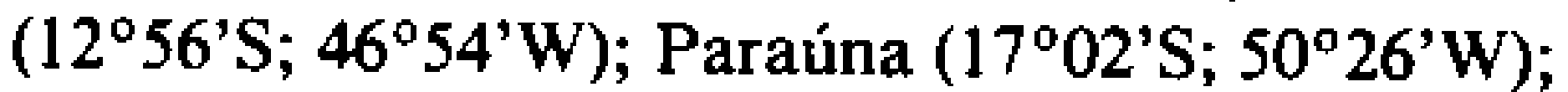

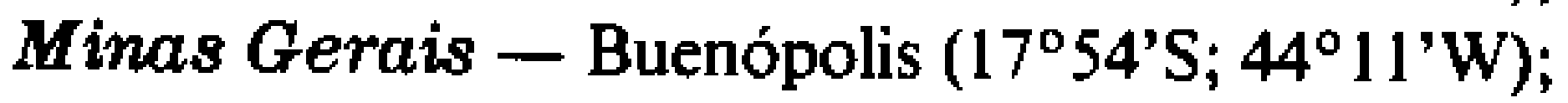
Diamantina (18 $\left.15^{\prime} \mathrm{S} ; 43^{\circ} 36^{\prime} \mathrm{W}\right)$; Janaúba

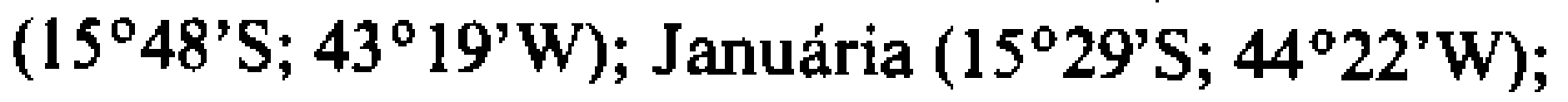
Porteirinha $\left(15^{\circ} 44^{\prime} \mathrm{S}\right.$; $\left.43^{\circ} 02^{\prime} \mathrm{W}\right)$; São João da Ponte (15 $56^{\prime} \mathrm{S}$; $\left.44^{\circ} 01^{\prime} \mathrm{W}\right)$; Mato Grosso Diamantino ( $\left.14^{\circ} 25^{\prime} \mathrm{S} ; 56^{\circ} 27^{\prime} \mathrm{W}\right)$; Mato Grosso do Sul-Aquidauana ( $20^{\circ} 28^{\prime} \mathrm{S}$; $55^{\circ} 48^{\prime} \mathrm{W}$ ); Bela Vista

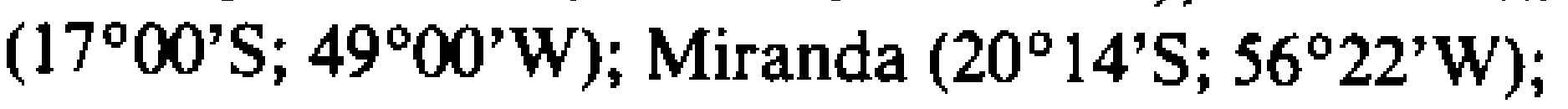
Nioaque ( $21^{\circ} 08^{\prime} \mathrm{S} ; 55^{\circ} 48^{\prime} \mathrm{W}$ ).

This species fits well in the series oswaldoi. The male was redescribed by Dias et al. (1986) 


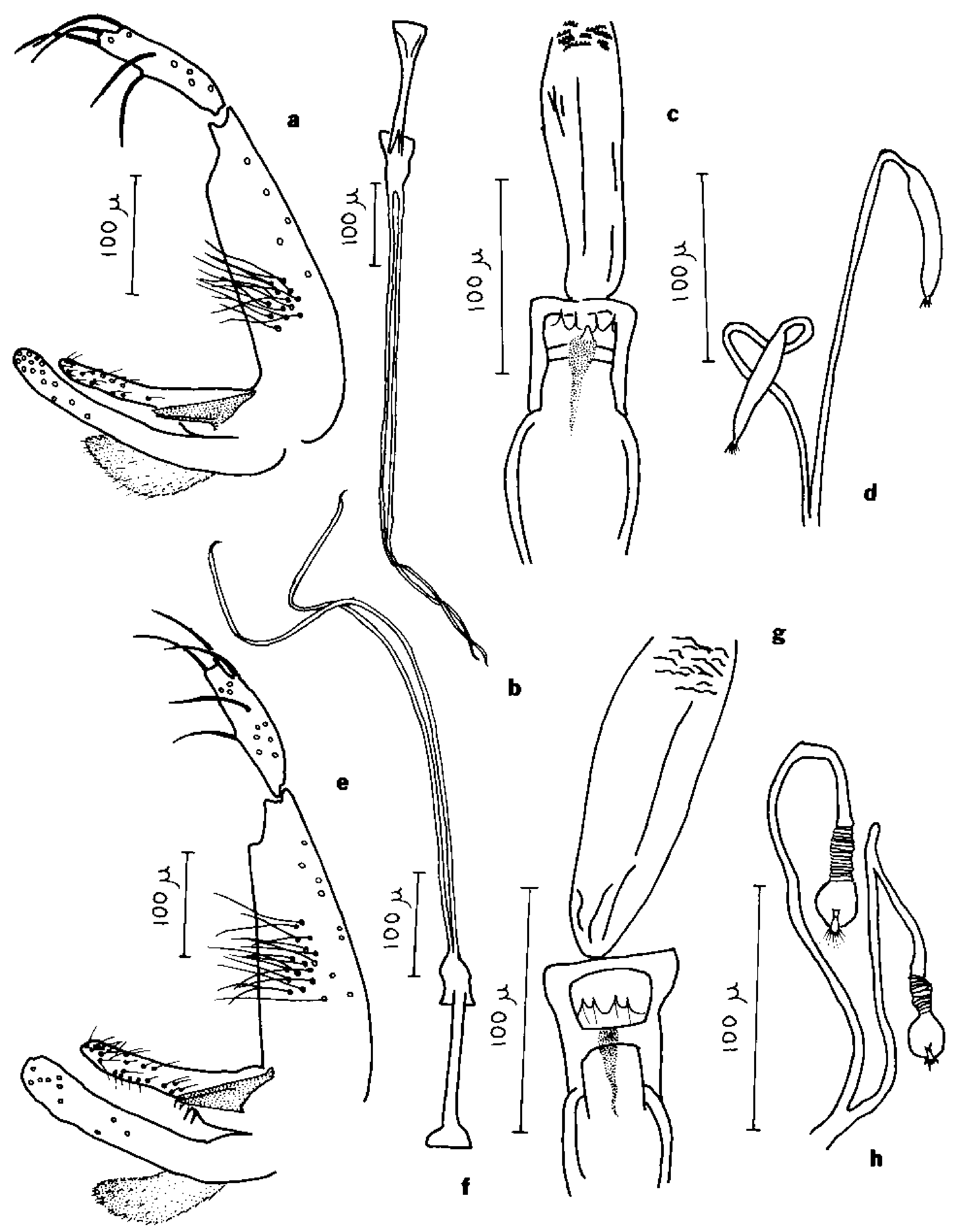

Fig. 3: - Lutzom yia goiana - a: terminalia: b: genital pump and filaments: $s$ : pharylis and cibarjum: d: spermathecae. Lutzomyia longipennis - e: terminalia: f: genital pump and filaments; g: pharymx and cibarium; h: spermathecae.

and it shows a small terminalia, shorter than its head.

The most similar Helcocyrtomyia species to $L$. peresi are $L$. goiana, $L$. rorotaensis and $L$. trinidadensis. The main features that character- ize $L$. peresi are the most developed clypeus, the absence of setae in the inner part of the basistyle and the arrangement of spines in the dististyle.

The female of $L$, peresi was first described and associated with the male by Dias et al. (1986). It 


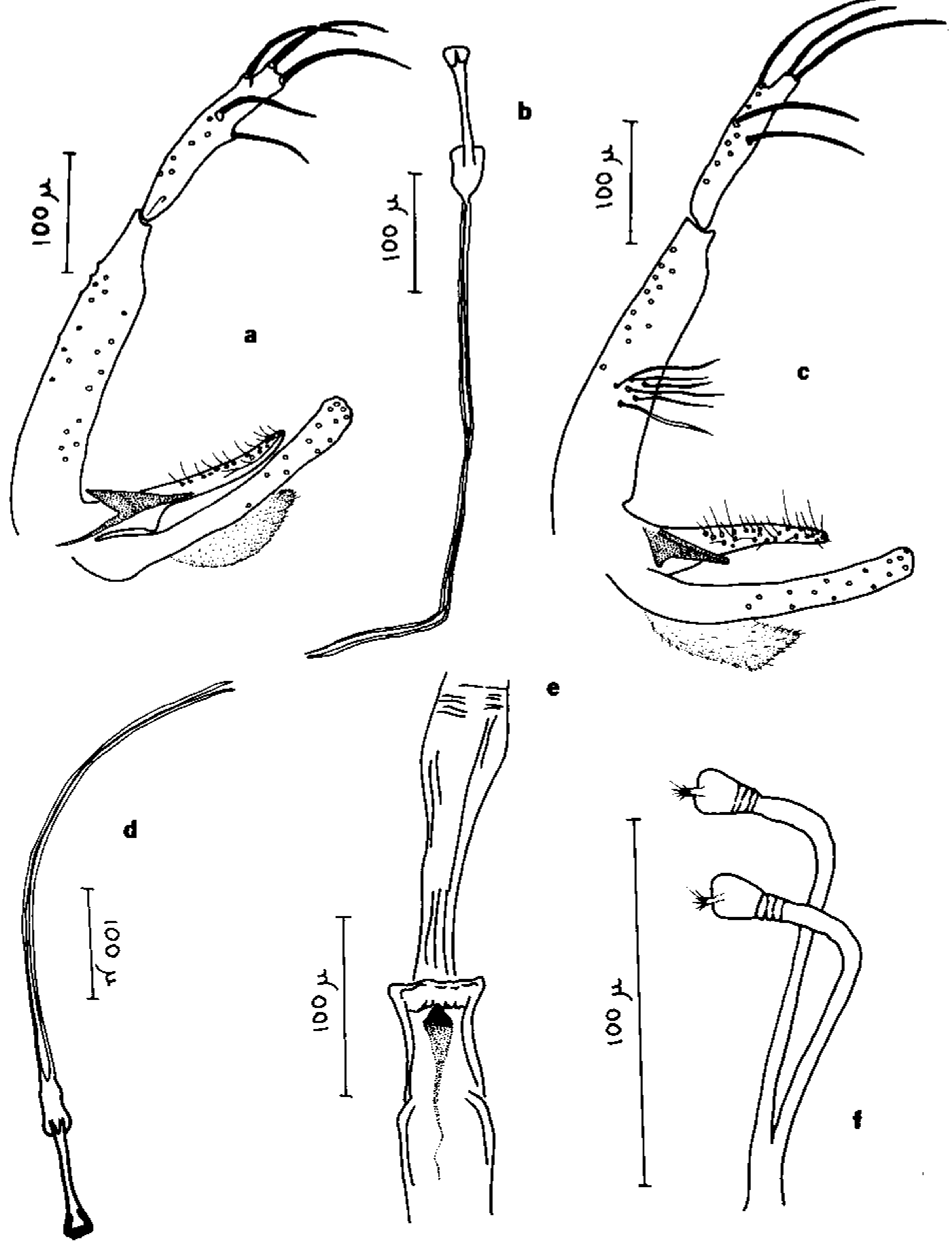

Fig. 4: Lutzomyia machupicchu - a: terminalia; b: genital pump and filaments. Lutzomyia oswaldoi - c: terminalia; d: genital pump and filaments; e: pharynx and cibarium; f: spermathecae.

shares a very unique feature with the females of L. oswaldoi, L. goiana and L. ferreirana: the presence of a chitinous structure projecting among the cibarial horizontal teeth. But they can be differentiated by the shape of the spermatheca that in $L$. peresi is elongated and segmented, with the 

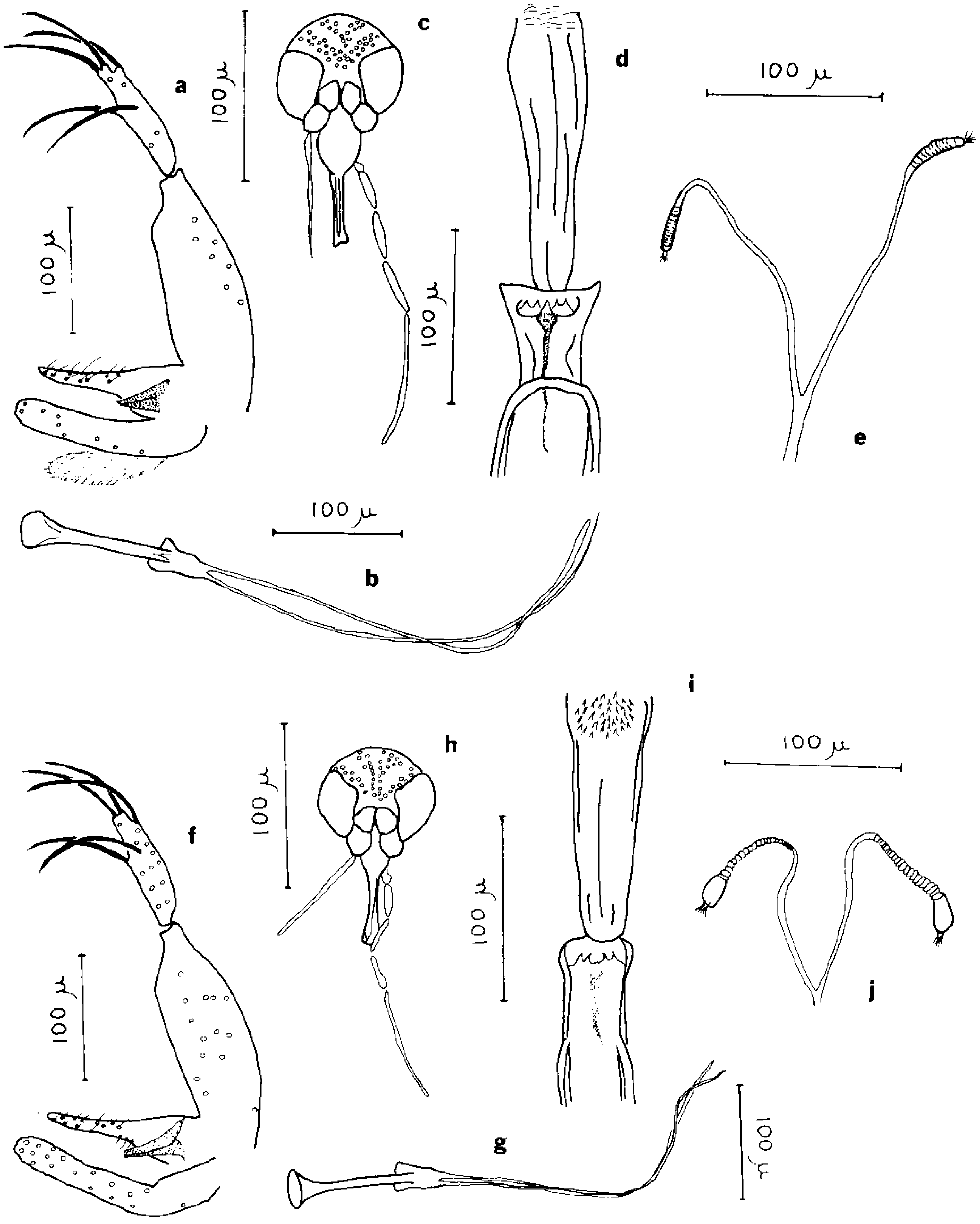

i
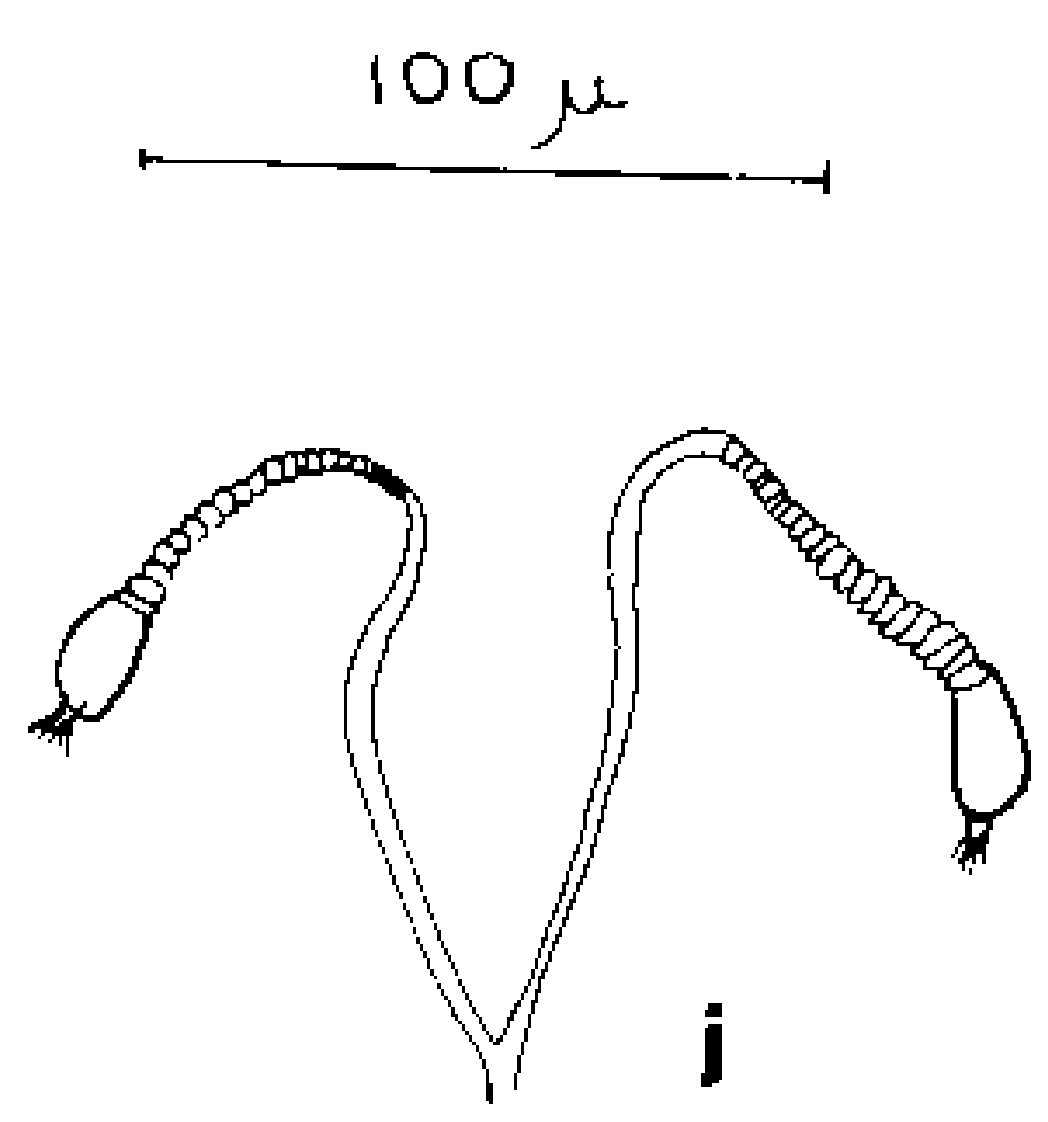

Fig. 5: Lutzomyia peresi - a: terminalia; b: genital pump and filaments; c: head; d: pharynx and cibarium; e: spermathecae. Lutzomyia pusilla - f: terminalia; g: genital pump and filaments; $h$ : head; i: pharynx and cibarium; j: spermathecae. 
last segmente more developed than in the others and showing a little "head".

\section{Lutzomyia (Helcocyrtomyia)pusilla}

Dias, Martins, Falcào \& Silva. (Fig. 4: f, g, h, i, j)

Phlebotomus peresi Floch \& Abonnenc, 1944. Inst. Pasteur Guyane et Territ. I'Inini, no. 90: 7, 20 (male). Phlebotomus sp. de Saul, Floch \& Abonnenc, 1944. Inst. Pasteur Guyane et Territ. I'Inini, no. 90: 21 (female). Lutzomyia pusilla Dias, Martins, Falcão \& Silva, 1986. Mem. Inst. Oswaldo Cruz, 81: 395-399 (male and female).

Types: holotype male (no. 37937) and allotype female (no. 37891) both deposited in CPqRR (FIOCRUZ), Belo Horizonte, Minas Gerais, Brazil. Type locality: Serra do Navio, Macapá municipality, Amapá state, Brazil.

Geographic distribution - BRAZIL: Ama pá - Macapá $\left(00^{\circ} 02^{\prime} \mathrm{S}\right.$; $\left.51^{\circ} 03^{\prime} \mathrm{W}\right) ;$ Pará Castanhal $\left(01^{\circ} 18^{\prime} \mathrm{S} ; 4^{\circ} 55^{\prime} \mathrm{W}\right)$; Irituia $\left(01^{\circ} 46^{\prime} \mathrm{S}\right.$; $47^{\circ} 26^{\prime} \mathrm{W}$ ); Oriximiná $\left(01^{\circ} 45^{\prime} \mathrm{S}\right.$; $55^{\circ} 52^{\prime} \mathrm{W}$ ). Mara. nhão - Cururupu $\left(01^{\circ} 50^{\prime} \mathrm{S} ; 4^{\circ} 52^{\prime} \mathrm{W}\right)$; Turiaçu $\left(01^{\circ} 41^{\prime} \mathrm{S} ; 45^{\circ} 21^{\prime} \mathrm{W}\right)$.

Lutzomyia pusilla has been described by Dias et al. (1986) and it is distinct from nearly all other species in the subgenus because of its small body size plus a terminalia smaller than the head. The only species that shows similar characteristics is $L$. peresi but, in addition to some differences in the measurements of structures of the clypeus, genital filaments and palpi (Dias et al., 1986), L. pusilla shows an armed pharynx with numerous stout spines and an elongate, more segmented spermatheca. In $L$. peresi the pharynx is unarmed.

\section{Lutzomyia (Helcocyrtomyia) rorotaensis}

(Floch \& Abonnenc) (Fig. 6: a, b, c, d)

Phlebotomus rorotaensis Floch \& Abonnenc, 1944. Inst. Pasteur G. Franc. et Territ. I'Inini, no. 90: 18-19 (male and female). Phlebotomus sp. de Rorota, Floch \& Abonnenc, 1941. Inst. Pasteur G. Franc. et Territ. I'Inini, no. 28: 10-11 (female). Lutzomyia (Trichopygomyia)trinidadensis (pro parte) Forattini, 1971. Pap. Av. Zool., 24: 102. Lutzomyia (Trichopygomyia)oswaldoi (pro parte) Forattini, 1973. Entomol. Méd., 4th vol.: 302.
Types: male (no. 119 bis) and female (no. 119) deposited in Instituto Pasteur de la Guyanne Française. Type locality: Rorota, French Guyana.

Geographic distribution - BRAZIL: Ama $p a ́$ - Macapá $\left(00^{\circ} 02^{\prime} \mathrm{N} ; 51^{\circ} 03^{\prime} \mathrm{W}\right)$. A mazonas - Manaus $\left(03^{\circ} 08^{\circ} \mathrm{S} ; 59^{\circ} 01^{\prime} \mathrm{W}\right)$. Maranhão Cururupu (01 $\left.{ }^{\circ} 50^{\prime} \mathrm{S} ; 4^{\circ} 52^{\prime} \mathrm{W}\right)$. Pará - Ananindeua $\left(01^{\circ} 22^{\prime} \mathrm{S}\right.$; $\left.48^{\circ} 23^{\prime} \mathrm{W}\right)$; Belém $\left(01^{\circ} 27^{\prime} \mathrm{S}\right.$; $\left.48^{\circ} 29^{\prime} \mathrm{W}\right)$; Castanhal $\left(01^{\circ} 18^{\prime} \mathrm{S} ; 4^{\circ} 59^{\prime} \mathrm{W}\right)$; Irituia - $\left(01^{\circ} 46^{\prime} \mathrm{S} ; 37^{\circ} 26^{\prime} \mathrm{W}\right)$. Roraima - Caracarai $\left(01^{\circ} 51^{\circ} \mathrm{N} ; 61^{\circ} 08^{\prime} \mathrm{W}\right)$. COLOMBIA: Antioquia Rio Anori $\left(07^{\circ} 10^{\prime} \mathrm{N}\right.$; $\left.75^{\circ} 05^{\prime} \mathrm{W}\right)$; Mutata $\left(07^{\circ} 14^{\prime} \mathrm{N}\right.$; $76^{\circ} 25^{\prime} \mathrm{W}$ ); Choco - Alto Curiche. Valle del Cauca - Buenaventura $\left(03^{\circ} 53^{\prime} \mathrm{N} ; 7^{\circ} 04^{\prime} \mathrm{W}\right)$; Lower Anchicaya Dam $\left(03^{\circ} 46^{\prime} \mathrm{N}\right.$; $\left.77^{\circ} 10^{\prime} \mathrm{W}\right)$; FRENCH GUYANA: Cayenne - Baduel $\left(04^{\circ} 56^{\prime} \mathrm{N}\right.$; 52 $\left.2^{\circ} 19^{\prime} \mathrm{W}\right)$; Cabassou $\left(04^{\circ} 53^{\prime} \mathrm{N}\right.$; $\left.52^{\circ} 18^{\prime} \mathrm{W}\right)$; Crique Anguille $\left(04^{\circ} 50^{\prime} \mathrm{N} ; 52^{\circ} 31^{\prime} \mathrm{W}\right)$; Matoury $\left(04^{\circ} 51^{\prime} \mathrm{N} ; 52^{\circ} 20^{\prime} \mathrm{W}\right)$; Montabo $\left(04^{\circ} 57^{\prime} \mathrm{N}\right.$; $\left.52^{\circ} 18^{\prime} \mathrm{W}\right)$; Rorota $\left(04^{\circ} 53^{\prime} \mathrm{N}\right.$; $\left.52^{\circ} 15^{\prime} \mathrm{W}\right)$. Haut $\mathrm{Ap}$ pronague - Balourou $\left(03^{\circ} 31^{\prime} \mathrm{N}\right.$; $\left.53^{\circ} 06^{\prime} \mathrm{W}\right)$; Saut Conori $\left(03^{\circ} 25^{\prime} \mathrm{N}\right.$; $\left.53^{\circ} 04^{\prime} \mathrm{W}\right)$; Saut Japaigny $\left(03^{\circ} 37^{\prime} \mathrm{N}\right.$; $\left.53^{\circ} 12^{\prime} \mathrm{W}\right)$; Saut Machicou $\left(04^{\circ} 21^{\prime} \mathrm{N}\right.$; $\left.54^{\circ} 16^{\prime} \mathrm{W}\right)$; Souvenir. Oyapock - Maripa $\left(03^{\circ} 48^{\prime} \mathrm{N}\right.$; $\left.51^{\circ} 53^{\prime} \mathrm{W}\right)$; Saint Georges $\left(03^{\circ} 45^{\prime} \mathrm{N}\right.$; $\left.52^{\circ} 05^{\prime} \mathrm{W}\right)$; Tampac $\left(03^{\circ} 12^{\prime} \mathrm{N}\right.$; 52 $\left.52^{\circ} 32^{\prime} \mathrm{W}\right)$. Sinnamary - Adieu-Vat $\left(04^{\circ} 52^{\prime} \mathrm{N}\right.$; $\left.53^{\circ} 00^{\prime} \mathrm{W}\right)$; Saint Elie $\left(04^{\circ} 50^{\prime} \mathrm{N} ; 53^{\circ} 17^{\prime} \mathrm{W}\right)$; Saut Tigre $\left(05^{\circ} 01^{\prime} \mathrm{N}\right.$; $\left.53^{\circ} 02^{\prime} \mathrm{W}\right)$; PERU: Puerto Maldonado (12 ${ }^{\circ} 50^{\prime} \mathrm{S}$; $69^{\circ} 20^{\prime} \mathrm{W}$ ); Madre de Dios.

The Helcocyrtomyia species that most resembles $L$. rorotaensis is $L$. trinidadensis mainly due to the similarity between both males. Some distinguishing features are the ratios between the genital filament/genital pump and flagellomere I/labrum-epipharynx, which are greater in $L$. rorotaensis and also the number of setae in the basistyle (10-14 in L. trinidadensis and 15-20 in L. rorotaensis).

Despite the similarity observed for the males, the females can be readily distinguished by the shape of the spermathecae and by the spines in the pharynx. In $L$. rorotaensis the spermathecae are segmented with the last segment globose while in L. trinidadensis they are not segmented and are sausage-shaped. The great number of spines in the pharynx of $L$. trinidadensis are replaced by some creases in $L$, rorotaensis.

Lutzomyia (Helcocyrtomyia) trinidadensis (Newstead) (Fig. 6: e, f, g, h) 


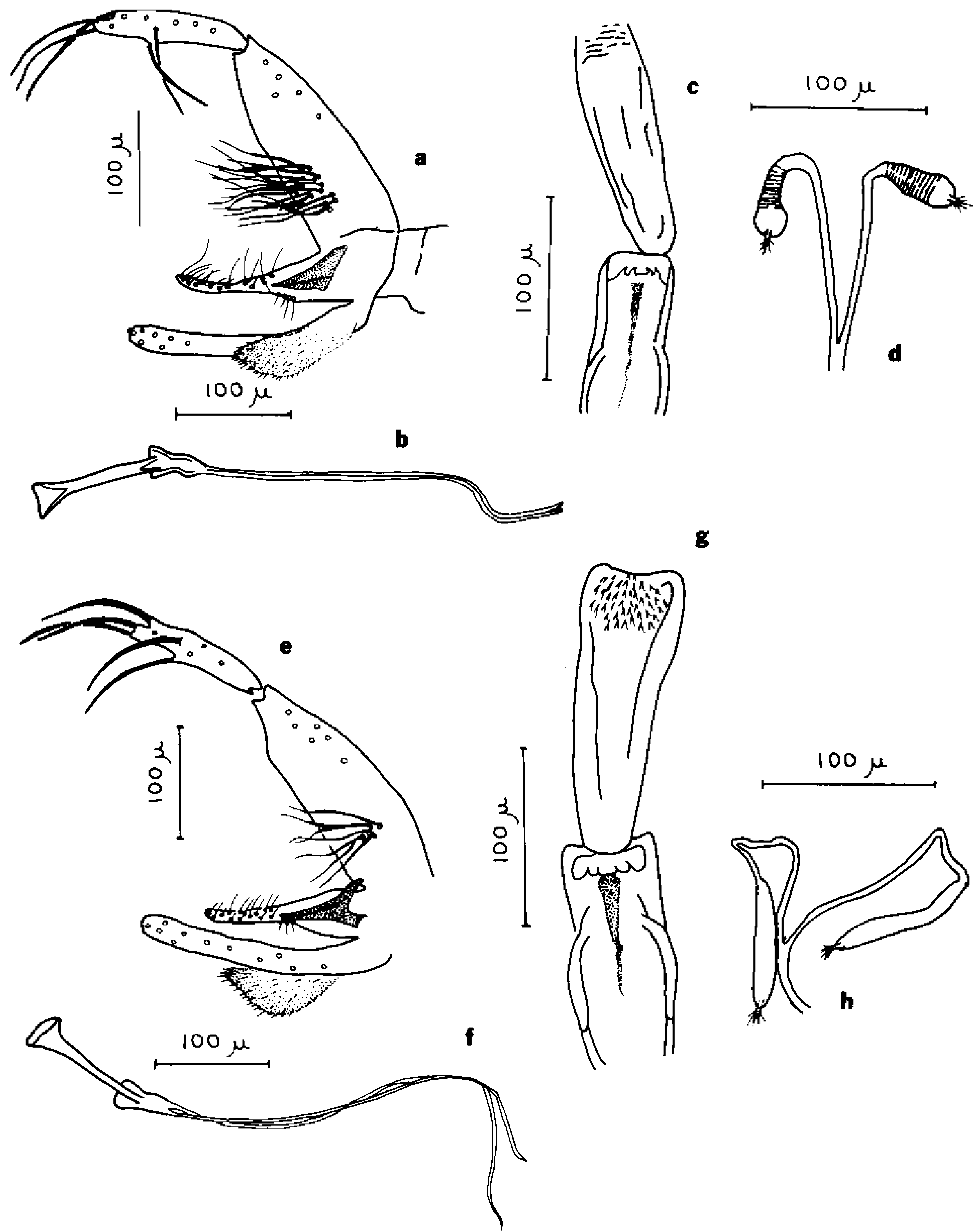

Fig. 6: Lutzomyia rorotaensis - a: terminalia; b: genital pump and filaments; c: pharynx and cibarium; d: spermathecae. Lutzomyia trinidadensis - e: terminalia; f: genital pump and filaments; $\mathrm{g}$ : pharynx; h: spermathecae.

Phlebotomus trinidadensis Newstead, 1922. An. Trop. Med. Parasit., 16: 47 (male and female). Fairchild \& Hertig, 1948. An. Entomol. Soc. America, 41: 253, 255-257 (male and female). Phlebotomus (Neophlebotomus) cruciatus Dyar, 1929. Am. J. Hyg., 10:119, 124. Phlebotomus yucatanensis Galliard, 1934. An. Parasitol. Hum. Comparée, 12: 1-6 (male and female). Phlebotomus yucatanensis var. baduelensis Floch \& Abonnenc, 1941. Inst. Pasteur G. Franc. et Territ. I'Inini, no. 15:
4-7 (male). Floch \& Abonnenc, 1941. Inst. Pasteur G. Franc. et Territ. I'Inini, no. 28: 1-3 (female). Phlebotomus longipalpis Ristocelli \& van Ty, 1941. An. Parasitol. Hum. Com. parée, 18: 72, 251-254 (female). Phlebotomus villelai Mangabeira, 1942. Mem. Inst. Oswaldo Cruz, s7: 196-198 (male). Phlebotomus villelai Dampf, 1947. An. Esc. Nac. C. Biol., 4: 432, 449 (female). Phlebotomus baduelensis Floch \& Abonnenc, 1944. Inst. Pasteur G. Franc, et Territ. I'Inini, no. 90: 2-4, 16-17 
(male and female). Lutzomyia (Trichopygomyia) trinidadensis Forattini, 1971. Pap. Av. Zool., 24: 102. Forattini, 1973. Entomol. Méd., 4th vol.: 321 (male, female, pupa, larva).

Type material - five males and five females deposited in the British Museum of Natural History, London, England. Type locality: Trinidad.

Geographic distribution - BELIZE: Augustine, Baking Pot $\left(17^{\circ} 12^{\prime} \mathrm{N} ; 8^{\circ} 01^{\prime} \mathrm{W}\right)$; Big Falls $\left(17^{\circ} 31^{\prime} \mathrm{N} ; 8^{\circ} 34^{\prime} \mathrm{W}\right) ;$ Bengue Viejo $\left(17^{\circ} 05^{\prime} \mathrm{N}\right.$; $\left.89^{\circ} 08^{\prime} \mathrm{W}\right)$; Arenal Road; Caves Branch $\left(17^{\circ} 14^{\prime} \mathrm{N}\right.$; $\left.8^{\circ} 35^{\prime} \mathrm{W}\right)$; Central Farm: Chiquibul Road; Esperanza $\left(17^{\circ} 26^{\prime} \mathrm{N}\right.$; 89 $\left.89^{\circ} \mathrm{\prime} \mathrm{W}\right)$; Guacamallo $\left(16^{\circ} 52^{\prime} \mathrm{N}\right.$; $\left.89^{\circ} 02^{\prime} \mathrm{W}\right)$; Hunning Bird Highway; Iguana Creek $\left(17^{\circ} 13^{\prime} \mathrm{N} ; 8^{\circ} 55^{\prime} \mathrm{W}\right)$; Millionario $\left(16^{\circ} 45^{\prime} \mathrm{N}\right.$; $\left.88^{\circ} 59^{\prime} \mathrm{W}\right) ;$ Mountain Pine Ridge $\left(16^{\circ} 53^{\prime} \mathrm{N}\right.$; $\left.88^{\circ} 55^{\prime} \mathrm{W}\right)$; Never Delay $\left(17^{\circ} 18^{\prime} \mathrm{N} ; 88^{\circ} 46^{\prime} \mathrm{W}\right)$; Never Delay Road; Punta Gorda $\left(16^{\circ} 07^{\prime} \mathrm{N} ; 88^{\circ} 48^{\prime} \mathrm{W}\right)$;

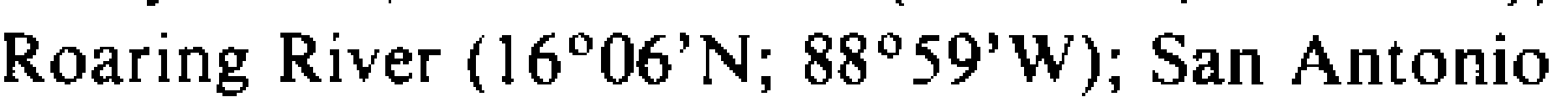
- Cayo Distric $\left(16^{\circ} 15^{\prime} \mathrm{N}\right.$; 89 $\left.8^{\circ} 02^{\prime} \mathrm{W}\right)$; San Antonio - Toledo District $\left(16^{\circ} 15^{\prime} \mathrm{N}\right.$; $\left.89^{\circ} 02^{\prime} \mathrm{W}\right)$; San Pedro Colombia (16 $17^{\circ} \mathrm{N}$; $8^{\circ} 58^{\prime} \mathrm{W}$ ); Sibun Camp

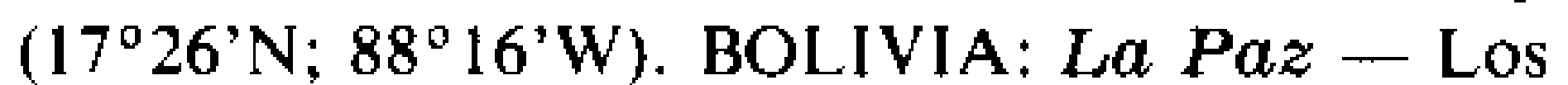
Yungas. BRAZIL: Acre - Feijó (08 $09^{\circ} \mathrm{S}$; $07^{\circ} 21^{\prime} \mathrm{W}$ ); Rio Branco (08 ${ }^{\circ} 14^{\prime} \mathrm{S}$; $\left.73^{\circ} 13^{\prime} \mathrm{W}\right)$; $\mathrm{Ama}$ pá - Macapá $\left(00^{\circ} 02^{\prime} \mathrm{N}\right.$; $\left.51^{\circ} 03^{\prime} \mathrm{W}\right)$; Amazonas

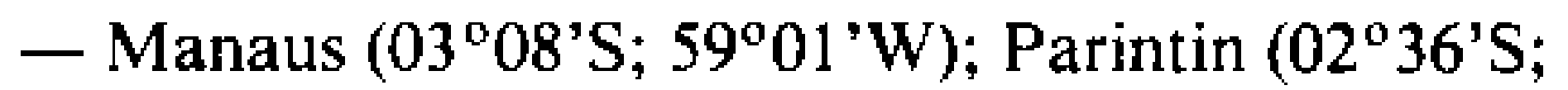
$\left.56^{\circ} 44^{\prime} \mathrm{W}\right)$; Bahia - Feira de Santana (12 $15^{\prime} \mathrm{S}$; $\left.38^{\circ} 57^{\prime} \mathrm{W}\right)$; Ceará - Aurora (06 $57^{\circ} \mathrm{S}$; $\left.38^{\circ} 58^{\prime} \mathrm{W}\right)$; Ipu (04 $\left.20^{\prime} \mathrm{S} ; 40^{\circ} 42^{\prime} \mathrm{W}\right)$; Itapipoca $\left(03^{\circ} 30^{\prime} \mathrm{S}\right.$; $\left.39^{\circ} 35^{\prime} \mathrm{W}\right)$; Maranguape $\left(03^{\circ} 53^{\prime} \mathrm{S}\right.$; $\left.38^{\circ} 40^{\prime} \mathrm{W}\right)$; Massape $\left(03^{\circ} 31^{\prime} \mathrm{S} ; 40^{\circ} 19^{\prime} \mathrm{W}\right)$; Pacatuba $\left(03^{\circ} 48^{\prime} \mathrm{S}\right.$; $\left.39^{\circ} 17^{\prime} \mathrm{W}\right)$; Santa Cruz do Norte; Santanople (07 $\left.{ }^{\circ} 11^{\prime} \mathrm{S} ; 39^{\circ} 44^{\prime} \mathrm{W}\right)$; Pará - Abaetetuba

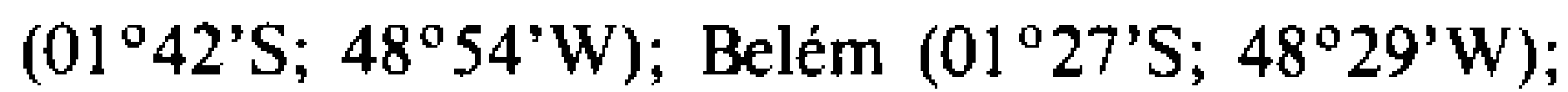
Igarape Açu (01 $\left.{ }^{\circ} 07^{\prime} \mathrm{S} ; 47^{\circ} 37^{\prime} \mathrm{W}\right)$; Irituia (01 ${ }^{\circ} 46^{\prime} \mathrm{S}$; $\left.4^{\circ} 26^{\prime} \mathrm{W}\right)$; João Coelho $\left(01^{\circ} 16^{\prime} \mathrm{S}\right.$; $\left.48^{\circ} 11^{\prime} \mathrm{W}\right)$; Monte Alegre (04.39'S; 52.49'W); Obidos

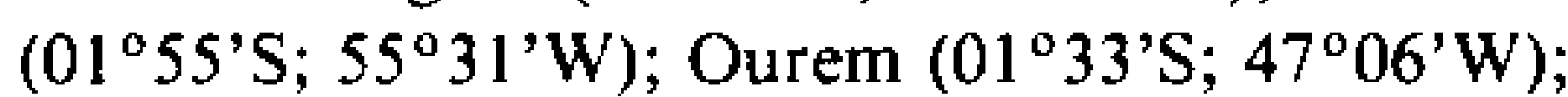
Peixe Boi $\left(01^{\circ} 12^{\prime} \mathrm{S} ; 4^{\circ} 18^{\prime} \mathrm{W}\right)$; Santarém (02 $30^{\circ} \mathrm{S}$; $\left.54^{\circ} 51^{\prime} \mathrm{W}\right)$; São Domingos do Capim (01\%41'S; $\left.47^{\circ} 47^{\prime} \mathrm{W}\right)$; São Miguel do Guama (01'37'S; $\left.47^{\circ} 27^{\prime} \mathrm{W}\right) ;$ Roraima - Boa Vista $\left(02^{\circ} 49^{\prime} \mathrm{N}\right.$;

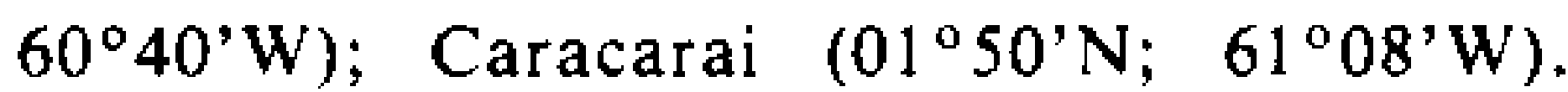
COLOMBIA: Antioquia - Anori $\left(07^{\circ} 10^{\prime} \mathrm{N}\right.$; $\left.75^{\circ} 05^{\prime} \mathrm{W}\right)$; Chigorodo $\left(07^{\circ} 41^{\prime} \mathrm{N} ; 7^{\circ} 42^{\prime} \mathrm{W}\right)$; inutata $\left(07^{\circ} 14^{\prime} \mathrm{N}\right.$; $\left.76^{\circ} 25^{\prime} \mathrm{W}\right) ;$ Bolivar - Mompos $\left(09^{\circ} 14^{\prime} \mathrm{N}\right.$; 74 $\left.{ }^{\circ} 26^{\prime} \mathrm{W}\right)$; Simiti (07 ${ }^{\circ} 58^{\prime} \mathrm{N}$; $\left.73^{\circ} 57^{\prime} \mathrm{W}\right)$;

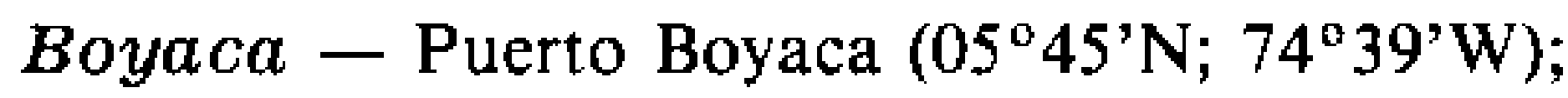
Caldas - La Dorada $\left(05^{\circ} 27^{\prime} \mathrm{N} ; 74^{\circ} 40^{\prime} \mathrm{W}\right)$; Victoria $\left(05^{\circ} 19^{\prime} \mathrm{N}\right.$; $\left.7^{\circ} 55^{\prime} \mathrm{W}\right)$; Cesar - Codazzi $\left(10^{\circ} 02^{\prime} \mathrm{N} ; 7^{\circ} 14^{\prime} \mathrm{W}\right)$; Valledupar $\left(10^{\circ} 29^{\prime} \mathrm{N}\right.$; $\left.73^{\circ} 15^{\prime} \mathrm{W}\right)$; Cudinamarca - La Mesa (04. $38^{\prime} \mathrm{N}$; $\left.74^{\circ} 28^{\prime} \mathrm{W}\right)$; Puerto Salgar $\left(05^{\circ} 28^{\prime} \mathrm{N}\right.$; $\left.74^{\circ} 39^{\prime} \mathrm{W}\right)$; Tocaima $\left(05^{\circ} 06^{\prime} \mathrm{N}\right.$; $\left.73^{\circ} 47^{\prime} \mathrm{W}\right) ;$ La Guajira Maicão (11 $23^{\prime} \mathrm{N}$; $\left.72^{\circ} 13^{\prime} \mathrm{W}\right)$; Uribia $\left(11^{\circ} 43^{\prime} \mathrm{N}\right.$; $\left.72^{\circ} 16^{\prime} \mathrm{W}\right)$; Urumita $\left(10^{\circ} 34^{\prime} \mathrm{N}\right.$; $\left.73^{\circ} 01^{\prime} \mathrm{W}\right)$; Huila Baraya $\left(03^{\circ} 10^{\prime} \mathrm{N}\right.$; $\left.72^{\circ} 50^{\prime} \mathrm{W}\right)$; La Plata $\left(02^{\circ} 23^{\prime} \mathrm{N}\right.$; $\left.75^{\circ} 53^{\prime} \mathrm{W}\right)$; Neiva $\left(02^{\circ} 56^{\prime} \mathrm{N}\right.$; $\left.75^{\circ} 18^{\prime} \mathrm{W}\right)$; Palermo $\left(02^{\circ} 54^{\prime} \mathrm{N}\right.$; $\left.75^{\circ} 26^{\prime} \mathrm{W}\right)$; Pitalito $\left(01^{\circ} 51^{\prime} \mathrm{N}\right.$; $\left.76^{\circ} 02^{\prime} \mathrm{W}\right)$; Tello $\left(03^{\circ} 04^{\prime} \mathrm{N} ; 7^{\circ} 08^{\prime} \mathrm{W}\right) ;$ Magdalema -

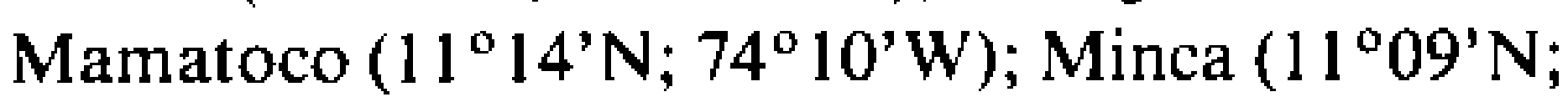
$\left.74^{\circ} 07^{\prime} \mathrm{W}\right)$; Parque Nacional Tayrona; Rio Don Diego (11 $\left.{ }^{\circ} 16^{\prime} \mathrm{N} ; 7^{\circ} 57^{\prime} \mathrm{W}\right)$; Santa Marta (11 ${ }^{\circ} 15^{\prime} \mathrm{N}$; $\left.74^{\circ} 13^{\prime} \mathrm{W}\right)$; Meta - Guanal (03 $52^{\prime} \mathrm{N}$; 73⒋ $\left.44^{\prime} \mathrm{W}\right)$; Villa Vicencio $\left(04^{\circ} 09^{\prime} \mathrm{N} ; 7^{\circ} 37^{\prime} \mathrm{W}\right)$; Nariño Valle del Capuli $\left(01^{\circ} 21^{\prime} \mathrm{N} ; 77^{\circ} 22^{\prime} \mathrm{W}\right)$; Norte de Santander - Cucuta (07 ${ }^{\circ} 54^{\prime} \mathrm{N}$; 72 $\left.2^{\circ} 31^{\prime} \mathrm{W}\right)$; Villa Del Rosario (07 $50^{\circ} \mathrm{N}$; $72^{\circ} 28^{\prime} \mathrm{W}$ ); Santander Guespsa $\left(06^{\circ} 01^{\prime} \mathrm{N}\right.$; $\left.73^{\circ} 34^{\prime} \mathrm{W}\right)$; Lebrija $\left(07^{\circ} 07^{\prime} \mathrm{N}\right.$; $\left.73^{\circ} 13^{\prime} \mathrm{W}\right)$; San Vicente de Chucuri $\left(06^{\circ} 54^{\prime} \mathrm{N}\right.$; $\left.73^{\circ} 25^{\prime} \mathrm{W}\right)$; Tolima - Armero (05 $05^{\prime} \mathrm{N}$;

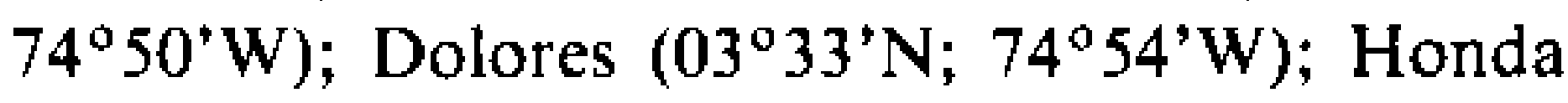
$\left(05^{\circ} 12^{\prime} \mathrm{N}\right.$; $\left.74^{\circ} 45^{\prime} \mathrm{W}\right)$; Melgar $\left(04^{\circ} 12^{\prime} \mathrm{N}\right.$; 74 $\left.39^{\circ} \mathrm{W}\right)$; Purificacion $\left(03^{\circ} 51^{\prime} \mathrm{N}\right.$; $\left.74^{\circ} 55^{\prime} \mathrm{W}\right)$; Saldana $\left(03^{\circ} 56^{\prime} \mathrm{N}\right.$; $\left.75^{\circ} 01^{\prime} \mathrm{W}\right)$. COSTA RICA: Esquinas (09.57'N; 84 $\left.04^{\circ} \mathrm{W}\right)$; Finca Socorrita; Jimenez de Guapiles $\left(10^{\circ} 13^{\prime} \mathrm{N}\right.$; $\left.83^{\circ} 43^{\prime} \mathrm{W}\right)$; Palmar (10 $00^{\circ} \mathrm{N}$; $\left.84^{\circ} 06^{\prime} \mathrm{W}\right)$; San Carlos $\left(10^{\circ} 00^{\prime} \mathrm{N}\right.$; 85 $\left.15^{\prime} \mathrm{W}\right)$. EQUADOR: Napo - Limoncocha $\left(00^{\circ} 24^{\prime} \mathrm{N}\right.$; $76^{\circ} 30^{\prime} \mathrm{W}$ ). FRENCH GUYANA: Cayenne -

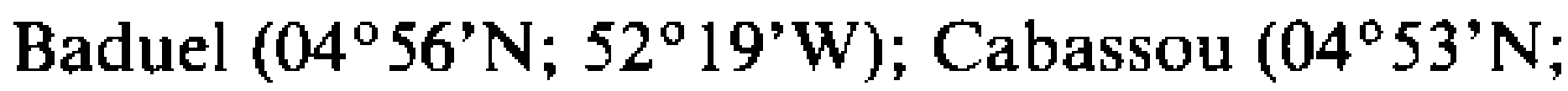
$\left.52^{\circ} 18^{\prime} \mathrm{W}\right)$; Illet la Mere, Montabo $\left(04^{\circ} 57^{\prime} \mathrm{N}\right.$; $\left.52^{\circ} 18^{\prime} \mathrm{W}\right)$; Rorota $\left(04^{\circ} 53^{\prime} \mathrm{N}\right.$; 52 $\left.2^{\circ} 15^{\prime} \mathrm{W}\right)$; Sinnamary - St. Elie $\left(04^{\circ} 50^{\prime} \mathrm{N} ; 53^{\circ} 17^{\prime} \mathrm{W}\right)$. HONDURAS: Lancetilla Valley - Tela (15 $44^{\prime} \mathrm{N}$; $\left.87^{\circ} 27^{\prime} \mathrm{W}\right)$. NICARAGUA: Villa Somoza $\left(12^{\circ} 08^{\prime} \mathrm{N}\right.$; 84 $\left.58^{\circ} \mathrm{W}\right)$. PANAMÁ: Colon - Quebrada Bonita $\left(09^{\circ} 51^{\prime} \mathrm{N}\right.$; 79.43'W); Darien - Altos de Duia $\left(08^{\circ} 08^{\prime} \mathrm{N}\right.$; $\left.77^{\circ} 41^{\prime} \mathrm{W}\right)$. Canal Zone - Gamboa $\left(09^{\circ} 07^{\prime} \mathrm{N}\right.$; $\left.79^{\circ} 42^{\prime} \mathrm{W}\right)$; Limbo Field Station. PERU: Cuzco - Chacoc $\left(12^{\circ} 43^{\prime} \mathrm{S}\right.$; $\left.72^{\circ} 37^{\prime} \mathrm{W}\right)$; Cuquipa-

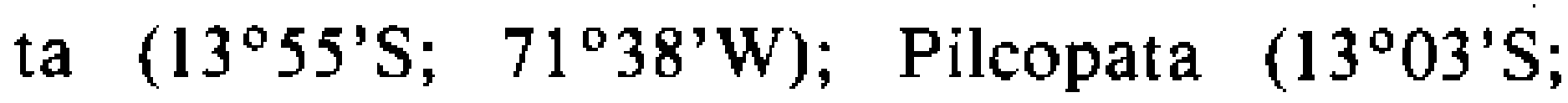
$\left.71^{\circ} 10^{\prime} \mathrm{W}\right) ;$ Loreto - Pucallpa (08 $23^{\prime} \mathrm{S}$; $\left.74^{\circ} 23^{\prime} \mathrm{W}\right)$; Yarinacocha; Madre de Dios - Iberia (05 $\left.48^{\prime} \mathrm{S} ; 7^{\circ} 00^{\prime} \mathrm{W}\right)$. TRINIDAD: Bus Bush Forest $\left(10^{\circ} 25^{\prime} \mathrm{N} ; 61^{\circ} 04^{\prime} \mathrm{W}\right)$. VENEZUELA: Aragua Barbacoas ( $10^{\circ} 25^{\prime} \mathrm{N}$; $64^{\circ} 14^{\prime} \mathrm{W}$ ); Casupito; Choroni $\left(10^{\circ} 29^{\prime} \mathrm{N}\right.$; 67 $\left.37^{\circ} \mathrm{W}\right)$; Curiepe; El Conejo; El Paraparo; El Rincon; Ingenio La Cruz; Jabillos; La Leiba; La Majada; La Pousada; Los Destiladores; Macapo; Ocumo; Onoto; Paya; Pedregal; Pie de Cerro; Porto Columbia; Rancho Grande ( $10^{\circ} 22^{\prime} \mathrm{N}$; $67^{\circ} 41^{\prime} \mathrm{W}$ ); Riacho Los Dos Hermanos;

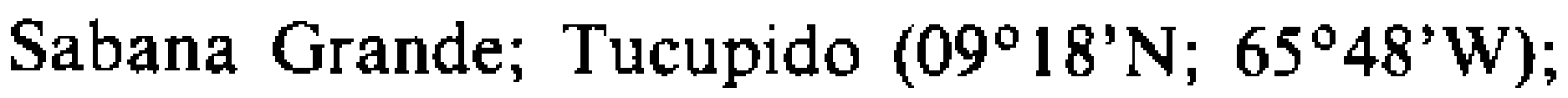
Falcon - Mene de Mauroa (10 $43^{\prime} \mathrm{N}$; $\left.71^{\circ} 01^{\prime} \mathrm{W}\right)$; Lara - Duaca $\left(10^{\circ} 18^{\prime} \mathrm{N} ; 69^{\circ} 10^{\prime} \mathrm{W}\right) ;$ Miranda - 

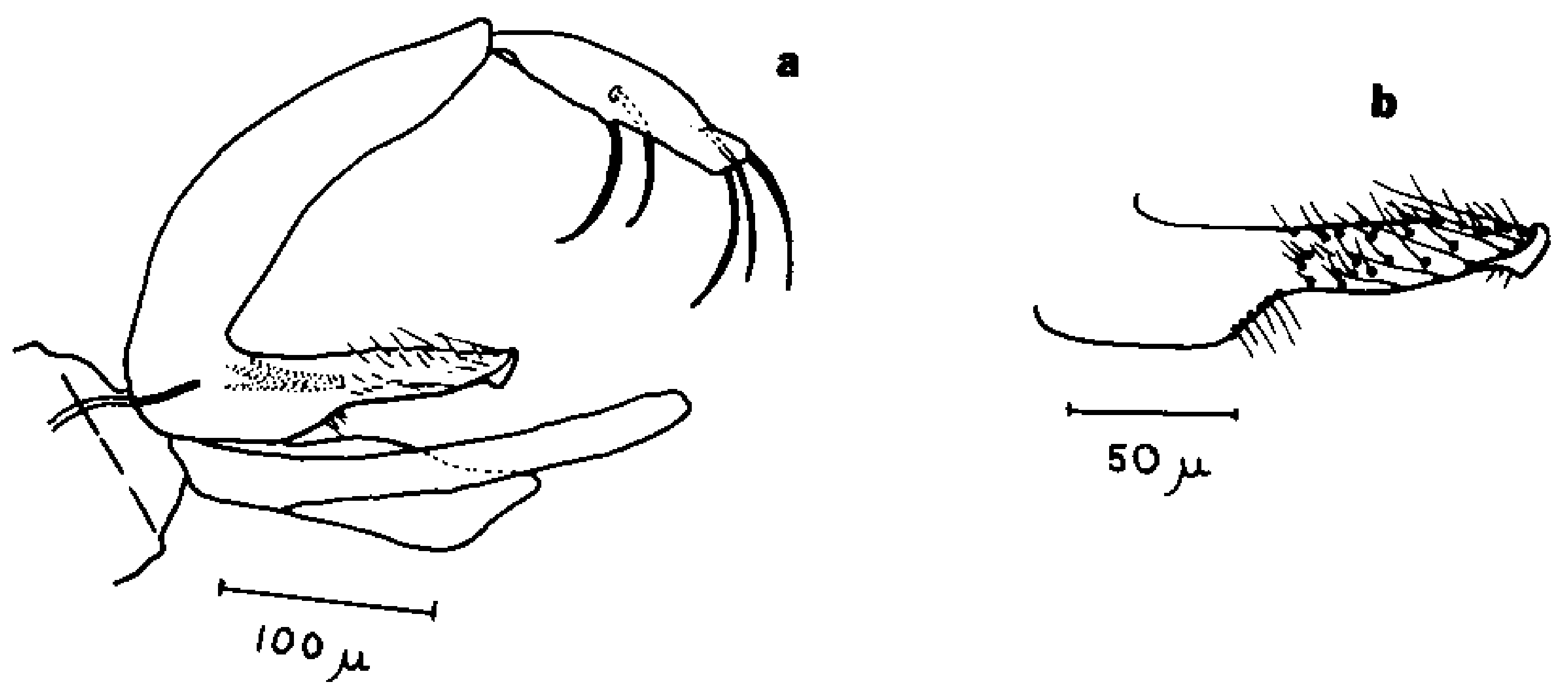

C
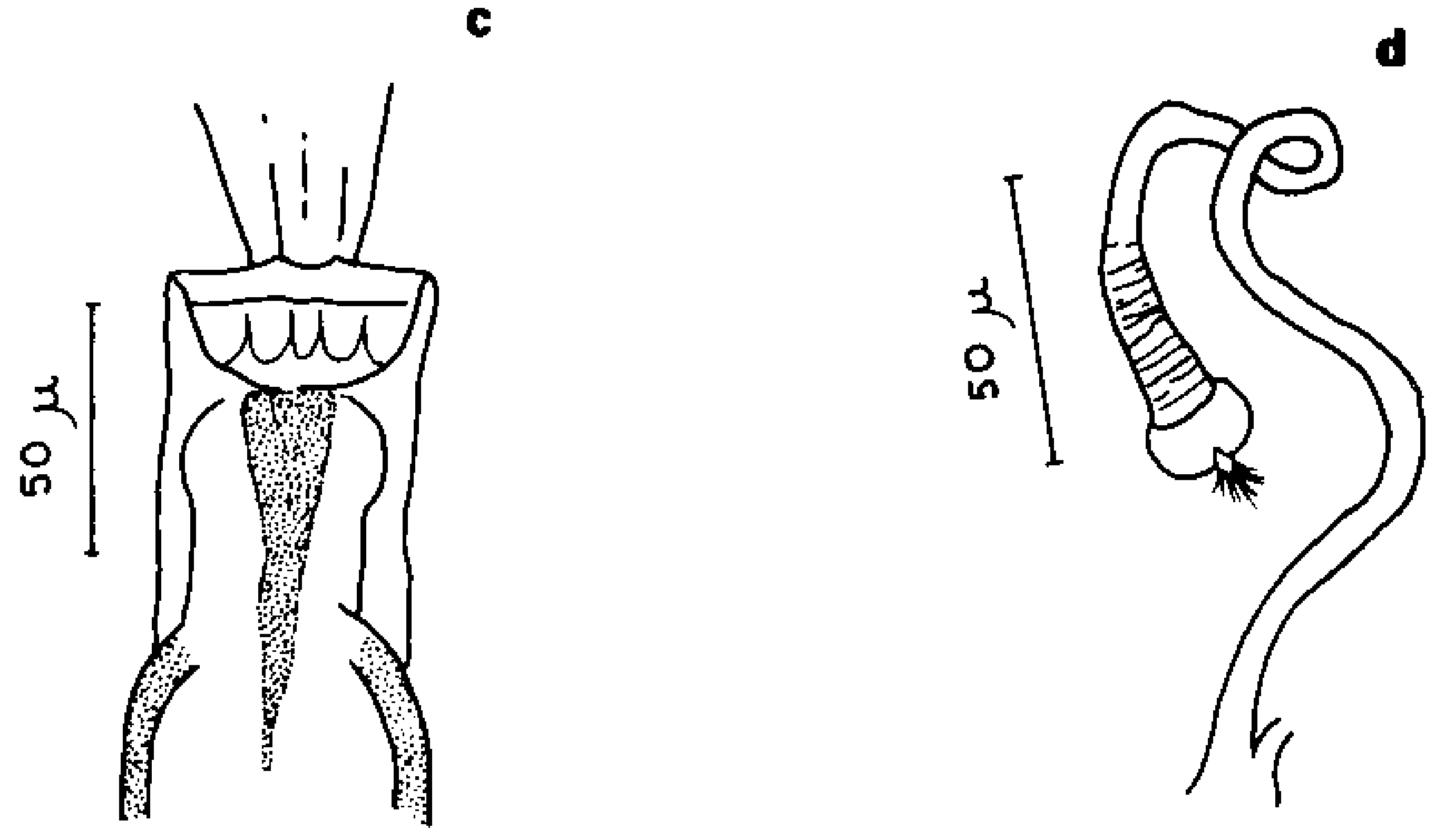

Fig. 7: Lutzomyia zikani - a: terminalia; b: paramere; c: cibarium; d: spermathecae (drawing by Barretto, 1950).

Guatopo; Nueva Sparta - Isla de Margarita $\left(11^{\circ} 00^{\prime} \mathrm{N} ; 64^{\circ} 00^{\prime} \mathrm{W}\right)$; Sucre - Concamure; Congrejal de Tres Picos $\left(07^{\circ} 48^{\prime} \mathrm{N}\right.$; $\left.67^{\circ} 49^{\prime} \mathrm{W}\right)$; Los Destiladores; Montana do Bentine; Montes $\left(10^{\circ} 15^{\prime} \mathrm{N}\right.$; $\left.63^{\circ} 55^{\prime} \mathrm{W}\right)$; Saboneta de Cedeno; San Fernando $\left(08^{\circ} 00^{\prime} \mathrm{N} ; 67^{\circ} 30^{\prime} \mathrm{W}\right)$; Sotilho de Arriba; Trujillo - Bolivia Capital (17 $\left.06^{\prime} \mathrm{S} ; 64^{\circ} 00^{\prime} \mathrm{W}\right)$; El Carrizal; El Manon; Mesa de Galliardo; Sabana Grande; Yaracuy - San Felipe $\left(10^{\circ} 20^{\prime} \mathrm{N} ; 68^{\circ} 44^{\prime} \mathrm{W}\right) ; Z u$. lia - Bachaquero $\left(09^{\circ} 56^{\prime} \mathrm{N}\right.$; $\left.71^{\circ} 08^{\prime} \mathrm{W}\right)$; Rio Negro $\left(09^{\circ} 40^{\prime} \mathrm{N}\right.$; $\left.72^{\circ} 01^{\prime} \mathrm{W}\right)$; Selva de Tamamaco $\left(09^{\circ} 49^{\prime} \mathrm{N} ; 68^{\circ} 20^{\prime} \mathrm{W}\right)$; Zipayare.

The subgenus Helcocyrtomyia possesses two other species very akin to $L$. trinidadensis, $L$. rorotaensis and $L$. goiana, due to the similarity observed between the males and between both sexes, respectively. The distinction between $L$. trinidadensis and $L$. rorotaensis is mainly due to the ratio between genital filament/genital pump, and flagellomere I/labrum-epipharynx that are respectively greater and smaller in $L$. trinidaden . sis, and to the number of bristles in the basistyle (10-14 for L. trinidadensis and $15-20$ in $L$. rorotaensis).

The main important difference between the males of $L$. trinidadensis and $L$. goiana are the shape of the paramere and the size of the clypeus. Both males show an enlarged-base paramere that narrows towards the top, but in $L$. goiana there is also a slighter bending upwards. The clypeus in $L$. goiana is also more developed than in $L$. trinidadensis.

The females of $L$. trinidadensis and $L$. goiana show very similar spermatheca, but they can be distinguished by the arrangement and the size of the spines in the distal third of the pharynx: they are stout and easily visible in 
L. goiana (Martins et al., 1962). Additionally, L. goiana possesses a chitinous stracture projecting among the cibarial horizontal teeth, which is absent in $L$. trinidadensis.

From the point of view of geographic distribution L. trinidadensis is found in the North of Brazil and Central America, whereas the incidence of $L$. goiana is restricted to Brazil.

\section{Lutzomyia (Helcocyrtomyia)zikani}

(Barretto) (Fig. 7: a, b, c, d)

Phlebotomus zikani Barretto, 1950. Fol. Clin. Biol., 16: 143-145, 147 (male and female).

Lutzomyia(Trichopygomyia)zikani Forattini, 1971. Pap. Av. Zool., 24: 102. Forattini, 1973. Entomol. Méd., 4th vol.: 325-326 (male and (emale).

Type: holotype male and allotype female, both deposited in the Departamento de Parasitologia da Faculdade de Medicina da Universidade de São Paulo, São Paulo, Brazil. Type locality: Jerusalém farm, Espirito Santo state, Brazil.

Geographic distribution: BRAZIL $-E s$ pirito Santo - Alegre (204' S; 41'32'W).

Unfortunately, this species was not examined as it was not present in the material studied. Although the male shows its own morphological characteristics, we observed a great similarity between the female described as $L$. zikani and the examined female of $L$. longipennis, that may suggest both as being a single species.

\section{REMARKS}

Throughout this work we have examined 7650 specimens of Helcocyrtomyia from the series oswaldoi. This series, as originally proposed by Martins et al. (1978), comprised the following fifteen species: $L$. appendiculata, $L$. borgmeieri, $L$. breviductus, L. ferreirana, L. goiana, L. longipennis, L. machupicchu, L. oswaldoi, $L$. paterna, L. peresi, L. pratti, L. rorotaensis, $L$. sordelli, L. trinidadensis, L. zikani.

According to our review, $L$. sordelli has been excluded from the subgenus as it was previously considered synonymy of $L$. nordestina (Young \& Morales, 1987). L. breviductus and L. pratti have been considered as species inquerenda. The first was described only by the male (Barretto, 1950) and showed five spines in the dististyle with only one in a terminal position instead of two, as it is typical of Helcocyrtomyia. L. pratti, also described only by the male, showed in a single specimen a different number and a distinct arrangement of spines in the dististyle as well: in one side, five spines of which two were terminal; in the other side six spines of which three were terminal (Vargas \& Diaz-Najera, 1951).

The type material of $L$. trinidadensis deposited in the British Museum of Natural History, London, England, has been recently reexamined by Williams (1988), attempting to refine the original description by Newstead (1922). The material available comprises five males and five females, and not six males and seven females as designed originally (Newstead, 1922). An holotype male plus a paralectotype female have been designed by Williams (1988), and the specimens examined in our work have showed morphological characters according to them. Among the species considered as synonymy of L. trinidadensis, Phlebotomus baduelensis (Floch \& Abonnenc, 1944) and Phle. botomus villelai (Mangabeira, 1942) were questioned by Williams, and he pointed to the necessity of a critical examination of both species before a definitive conclusion. So, we have maintained them as synonymys, until further studies.

Two new species have been described and incorporated in the subgenus Helcocyrtomyia: $L$. pusilla Dias, Martins, Falcão \& Silva, 1986, and L. capixaba Dias, Falcão, Silva \& Martins, 1987. The females of these new species lack cibarial vertical teeth, according to the first characteristics of the series oswaldoi. Other characteristics, spermathecae pear-shaped weakly annulated with a globose terminal segment, are observed only in $L$. capixaba. L. pusilla has elongated spermathecae, strongly annulated with the last terminal segment globose. Despite of this, we considered that the species fits well within the series oswaldoi.

Additionally, the males of $L$. peresi and $L$. ferreirana have been redescribed and their females have been desciibed, as a result of this work. $L$. ferreirana has also been included in the series oswaldoi, although presenting two proeminent cibarial vertical teeth.

From the classical systematics point of view and according to our study, the series oswaldoi of the 
subgenus Helcocyrtom yia comprises fourteen species, of which twelve were examined (see Table). Other species, named Lutzom yia sacrai, from the series oswaldoi has been recently described in Venezuela by Feliciangeli (1989). L. zikani and $L$. paterna were not avalable for examination.

\section{TABLE}

Frequency of species of the examined material from the series oswaldoi, subgenus Helcocyrtomyia, genus Lutzom yia (Diptera, Psychodidae. Phlebotominae)

\begin{tabular}{lrrr}
\hline \multirow{2}{*}{ Species } & \multicolumn{3}{c}{ Number of specimens } \\
\cline { 2 - 4 } & \multicolumn{2}{c}{ do } & f $/$ subtotal \\
\hline L. appendiculata & 1 & - & 1 \\
L. borgmeieri & 602 & 154 & 756 \\
L. capixaba & 330 & 66 & 396 \\
L. ferreirana & 123 & 38 & 161 \\
L. goiana & 660 & 128 & 788 \\
L. longipennis & 508 & 88 & 596 \\
L. machupicchu & 1 & - & 1 \\
L. osualdoi & 73 & 15 & 88 \\
L. peresi & 252 & 114 & 366 \\
L. pusilla & 128 & 25 & 153 \\
L. rorotaensis & 2423 & 499 & 2922 \\
L. trinidadensis & 922 & 500 & 1422 \\
\hline Total & 6023 & 1627 & 7650 \\
\hline
\end{tabular}

\section{ACKNOWLEGMENTS}

To Dr Paul Williams, who has gently furnished the geographical coordinates of the great majority of localities, and to Mrs Regina Maria de Oliveira Rezende for excellent technical help.

\section{REFERENCES}

ANDERSON, J. R. \& AYALA, S. C., 1968. Trypanosome transmitted by Phlebotomus: first report from the Americas. Science, 161: 1023-1025.

AYALA, S. C., 1971a. Sporogony and experimental transmission of Plasmodium mexicanum. $J$. Parasitol., 57: 598-602.

AYALA, S. C., 1971b. Trypanosomes in wild California sandflies, and extrinsic stages of Trypanosoma bufophlebotomi. J. Protozool., 18: 433-436.

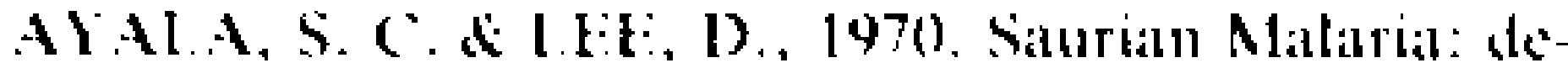
velopment it spororoites in two species of phlebotemine sindflies. Science, 167: 891-892.

BARRETTO. M. P., 1950. Duas nowas especies de flebotomus brasileiros (Diptera, Psychodidate). Fol. Clin. Biol., 16: 14-149.

B.ARRETTO, M1. P.. 1962. Novos subgeneros de Lut. zom yia França (Diptera. Psychodidae, subfamilia Phlebotominael. Re'. Inst. Med. Trop. Saio Pau. lo. 4: $91-100$.

BARRETTO, M. P. \& COLITINHO, I. O., 1940. Processos de captura. transporte, disseccào e montagem de flebotomos. An. Fac. Med. Unir. São Paulo, 16: 173.187.

CHANIOTIS, B. N. \& ANDERSON. J. R.. 1964. Notes on the morphology and laboratory rearing of Phle. botomus vexator occidentis. The Pan-Pacific Entomologist. 40: 27-32.

CHANIOTIS, B. N. \& ANDERSON, J. R., 1968. Age structure, population dynamics and vector potential of Phlebotomus in northern California. J. Med. Entomol. 5: 273-292.

DAMIASCENO, R. M. G.. 1955. Contribuiçào Entomologica - Descriçào de um método de captura de insetos em troncos de árvores, buracos na terra e tocas de animais silvestres. In Congresso Brasileiro de Higiene, 13, Belem.

DIAS. E. S.; MARTINS A. L. \& SILVA. J. E., 1986. Redescrição do macho e descrição da fèmea de $L u t$. zomyia (Hecocyrtomyia) peresi (Mangabeira, 1942) (Diptera, Psychodidae, Phlebotominae). Mem. Inst. Oswaldo Cruz, 81: 215-219.

DIAS, E.S.; MARTINS A . V.; FALCĀO A. L. \& SILVA J. E., 1987. Descrição de uma nova espécie do subgènero Helcocyrtom yia, Lutzom yia capixaba sp.n. (Diptera, Psychodidae, Phlebotominae). Mem. Inst. Oswaldo Cruz, 82: 193-196.

DIAS, E. S.; FALCĀO A. L.; SILVA, J. E. \& MARTINS A. V., 1989. Redescrição do macho e descrição da fêmea de Lutzomyia (Helcocyr. tomyia)ferreirana (Barretto, Martins \& Pellegrino, 1958) (Diptera, Psychodidae, Phlebotominae). Mem. Inst. Oswaldo Cruz, 84: 245-248.

FALCĀO, A. R., 1981. Um novo modelo de armadilha luminosa de sucção para pequenos insetos. $\mathrm{Mem}$. Inst. Oswaldo Cruz, 76: 303-305.

FAIRCHILD, G. B., 1955. The relationships and classifications of the Phlebotominae (Diptera, Psychodidae). An. Entomol. Soc. America, 48: 182-196.

FELICIANGELI, M. D., 1989. Taxonomy and distribution of phlebotominae sandflies in Venezuela. 1 . The oswaldoi species group of the genus Lutzomyia (Diptera: Psychodidae). Mem. Inst. Oswaldo Cruz, 84: 333-341.

FORATTINI, O. P., 1973. Entomologia Médica. IV. Psychodidae, Phlebotominae. Leishmanioses, Bartonelose. Ed. Blucher, São Paulo. 658 p.

HERTIG, M., 1942. Phlebotomus and Carrion's disease. III - Field studies on Phiebotomus. Am. J. Trop. Med., 22: 23-60.

MARTINS, A. V.; FALCÃO, A. L. \& SILVA, J. E., 
1962. Nota sobre os flebótomos do Estado de Góias, com a descrição de duas espécies novas e da fêmea de Lutzomyia longipennis (Barretto, 1946) e a redescrição de macho de Lutzomyia evandroi (Costa Lima \& Antunes, 1936) (Diptera, Psychodidae). Rev. Bras. Malariol. D. Trop., 14: 379-398.

MARTINS, A. V.; LLANOS, B. Z. \& SILVA, J. E., 1975. Estudos sobre os flebotomineos do Peru (Diptera, Psychodidae, Phlebotominae). 1 - Departamento de Cuzco: 1 - Descrição de três esnécies novas. Rev. Bras. Biol., 35: 645-654.

MARTINS, A. V.; WILLIAMS, P. \& FALCÃO, A. L., 1978. American Sand Flies. (Diptera: Psychodidae, Phlebotominae). Rio de Janeiro, Academia Brasileira de Ciências.

NEWSTEAD, R., 1922. A new species of Phlebotomus from Trinidad. An. Trop. Med. Parasitol, 16: 47-50.

NOGUCHI, H.; SHANNON, R.C.; TILDEN, E. B. \& TYLER, J. R., 1929. Etiology of Oroya Fever, XIV - The insect vectors of Carrion's disease. J. Exp. Med., 49: 993-1008.

PACKCHANIAN, A., 1946. The distribution of species of sandflies genus Phlebotomus, in the United States and their relations to the transmission of Leishmaniasis. Texas Report Biol. Med., 4: 35-41.

PESSOA, S. B. \& MARTINS, A, V., 1986. Parasitolo. gia Médica. 11 ed. Rio de Janeiro, Guanabara Koogan, $872 \mathrm{p}$.
QUATE, L. W., 1963. Fossil Psychodidae in Mexican Amber, Part, 2. (Diptera insecta). J. Paleontol., \$4: 113-114.

SHANNON, R. C., 1913. Feeding habits of Phlebotomus vexator Coq. Proc. Entomol. Soc., 15: 165-169.

SHANNON, R. C., 1929. Entomological investigation in connection with Carrion's disease. $A m$. J. Hyg., 10: 78-111.

SHANNON, R, C., 1939. Methods for collecting and feeding mosquitoes in jungle yellow fever studies. $A m$. J. Trop. Med., 19: 131-140.

SHERLOCK, I.A. \& PESSOA, S.B., 1964. Métodos práticos para a captura de Flebótomos. Rev. Bras. Biol., 24: 331-340.

VARGAS, L. \& DIAZ-NAJERA, A., 1951. Phlebotomus prattin. sp. de Iguala, Estado de Guerrero (Insecta: Diptera). Bol. Inst. Studios Med. y Biol. 9: 19-23.

WILLIAMS, P., 1988. Notes on Lutzomyia (Hel. cocyrtomyia) trinidadensis (Newstead, 1922) (Diptera: Psychodidae-Phlebotominae). Mem. Inst. Oswaldo Cruz, 83: 375-383.

YOUNG, D. G. \& MORALES, A., 1987. New species and records of Phlebotominae sand flies from Colombia (Diptera: Psychodidae). J. Med. Entomol., 24: $651-665$. 